2001

\title{
Patterns of Lending to Low-Income and Minority Persons and Neighborhoods: The 1999 New York Metropolitan Area Lending Scorecard
}

Richard D. Marsico

New York Law School

Follow this and additional works at: http://digitalcommons.nyls.edu/fac_articles_chapters

Part of the Banking and Finance Law Commons, and the Housing Law Commons

\section{Recommended Citation}

17 N.Y.L. Sch. J. Hum. Rts. 199 (2000-2001)

This Article is brought to you for free and open access by the Faculty Scholarship at DigitalCommons@NYLS. It has been accepted for inclusion in Articles \& Chapters by an authorized administrator of DigitalCommons@NYLS. 


\title{
Patterns of Lending to Low-Income and Minority Persons and Neighborhoods: The 1999 New York Metropolitan Area Mortgage Lending Scorecard
}

\author{
Richard D. Marsico ${ }^{1}$
}

INTRODUCTION

This is the second in a series of annual reports ${ }^{2}$ on residential real estate-related lending ${ }^{3}$ and conventional home mortgage lending ${ }^{4}$ to minority and low- and moderate-income (LMI) persons and neighborhoods in the New York metropolitan area (New York or the metropolitan area). ${ }^{5}$ In 1991, disclosure of detailed data about home mortgage lending in these communities showed that their credit needs were not being met. $^{6}$ Immediately thereafter, government officials, community groups, and lenders started to work to increase home mortgage lending in these communities. ${ }^{7}$ For several years thereafter, lending in these communities grew relative to other communities, but then the relative growth began to slow. ${ }^{8}$ The purpose of this annual Scorecard is to examine yearly trends in residential real estate-related and conventional home mortgage lending in these communities. The

${ }^{1}$ Professor of Law, New York Law School. I wish to thank Vicki Hurewitz for all of her assistance with this report. I also thank New York Law School for its support of my research and Danielle Petito for her patience and hard work.

${ }^{2}$ For the first report, see Richard D. Marsico, New York Metropolitan Area Lending Scorecard: 1998, 16 N.Y.L. ScH. J. HUM. RTS. 769 (2000) (1998 Scorecard). Portions of the 1999 Scorecard, particularly those dealing with methodology, are reprinted from the 1998 Scorecard.

${ }^{3}$ This Scorecard defines "residential real estate-related lending" as including government-insured home mortgage loans, conventional home mortgage loans, home mortgage refinance loans, home improvement loans for residential real estate, and multifamily home purchase loans.

${ }^{4}$ This Scorecard defines "conventional home mortgage lending" as including loans to purchase a one-to-four family residential property, excluding government-insured loans.

${ }^{5}$ More specifically, the Scorecard covers Metropolitan Statistical Area 5600 , which includes eight counties: Bronx, Kings, New York, Queens, Richmond, Rockland, Putnam, and Westchester.

${ }^{6}$ See Richard D. Marsico, Shedding Some Light on Lending: The Effects of Expanded Disclosure Laws on Home Mortgage Marketing, Lending and Discrimination in the New York Metropolitan Area, 27 FORD. URB. L.J. 481 (1999).

${ }^{7}$ Id.

${ }^{8} \mathrm{Id}$. 
Scorecard will provide information for lenders, government officials, community groups, borrowers, and other interested parties to help them develop policies, programs, and strategies to ensure that sufficient mortgage credit is available to minority and LMI persons and neighborhoods.

Reflecting this goal, the 1999 Scorecard includes two significant additions. First, it includes more data about "subprime" lending to lowincome and minority borrowers and neighborhoods than the 1998 Scorecard. Subprime lenders specialize in making higher-priced loans to borrowers with less than " $A$ " rated credit, the so-called "subprime" market." Although subprime lending serves an important function by providing credit to people with imperfect credit histories, it is also subject to abusive practices. ${ }^{10}$ Several subprime lenders have been accused of "predatory lending" in low-income and minority neighborhoods, using high-pressure sales tactics to induce vulnerable borrowers to agree to unconscionable credit terms. ${ }^{11}$ These terms include high interest rates, negative amortization, hidden fees and penalties, and balloon payments, and frequently result in higher than average rates of foreclosure. ${ }^{12}$ Subprime lenders have also been accused of discriminatory lending practices, including charging subprime minority borrowers higher rates and fees than subprime White borrowers and not making lower-priced prime credit available to qualified minority borrowers. ${ }^{13}$ Subprime and

${ }^{9}$ See Glenn B. Canner \& Wayne Passmore, The Role of Specialized Lenders in Extending Mortgages to Lower-Income and Minority Homebuyers, 85 FED. RES. BULL. 709, 715-716 (1999); Bill Dedman, Study Discerns Disadvantages for Blacks in Home Mortgages, N.Y. TIMES, Nov. 14, 1999, at 18; Katharine Fraser, Revised Fair-Lending Exams Include Subprime and Auto, AM. BANKER, Sept. 14, 1999, at 2; Daniel Wise, State Agencies Finally Reach Pact Over Lender Abuse, N.Y.L.J., Sept. 23, 1999, at 1.

${ }^{10}$ Letter from John A. Joyce, Secretary of the New York State Banking Board, to Each Institution Addressed 2 (Dec. 28, 1999); Canner \& Passmore, supra note 9, at 751; Dedman, supra note 9.

${ }^{11}$ See Dedman, supra note 9; Heather Timmons, Subprime Lender Delta Agrees to \$6M Settlement with New York Attorney General, AM. BANKER, June 24, 1999, at 28; Wise, supra note 9.

${ }^{12}$ See Dedman, supra note 9; Timmons, supra note 11.

${ }^{13}$ Court Rules Predatory Lending May Violate Fair Housing Act, Judge Leaves it to Jury to Decide What is Unfair or Abusive, INSIDE MORTGAGE COMPLIANCE, Oct. 16, 2000, at 2; Randy Kennedy, Home Lender Settles Suit Over Fees, N.Y. Times, Mar. 31, 2000, at B1; Raun J. Rasmussen, Predatory Lending Litigation Update, N.Y.L.J., Feb. 17, 2000, at 1; Use of Race to Target Communities for Unfair Loans is Illegal, Lending that Makes Housing 'Unavailable' Violates FH Act, InSIDE MoRTGAGE CoMPLIANCE, Apr. 3, 
predatory lending have recently received much attention by government officials and community advocates, who have undertaken several initiatives to curtail abusive lending practices. ${ }^{14}$

2000 , at 2 .

${ }^{14}$ For example, in July 2000, the New York State Banking Department adopted new Part 41 of the General Regulations of the Banking Board, which regulates "high cost" home loans. See (visited February 23, 2001) <http://www.banking. state.ny.us/4lamd2.htm>. Almost immediately thereafter, the Department circulated a letter seeking comments on a proposal to reduce the interest-rate threshold for defining a "high cost" home loan. See Letter from Alvin A. Narin, Acting Secretary to the Banking Board, to Each Institution or Individual Addressed (July 17, 2000). The Federal Reserve undertook several initiatives. It held a series of hearings on predatory lending practices and proposals to limit them. See Press Release, Board of Governors of the Federal Reserve System (released July 19, 2000). It also sought comments on proposed amendments to its regulations under the Home Mortgage Disclosure Act (HMDA) and the Homeownership Equity Protection Act (HOEPA) designed to combat predatory lending. See Press Release, Board of Governors of the Federal Reserve System (released November 29, 2000) (HMDA regulations), and Press Release, Board of Governors of the Federal Reserve System (released December 19, 2000) (HOEPA regulations). Four federal banking regulatory agencies, the Federal Reserve, the Federal Deposit Insurance Corporation, the Office of the Comptroller of the Currency, and the Office of Thrift Supervision issued a regulatory guidance statement relating to subprime lending. Joint Release, Banking Agencies Issue Guidance On Supervision of Subprime Lending, Board of Governors of the Federal Reserve System, Federal Deposit Insurance Corporation, Office of the Comptroller of the Currency, and Office of Thrift Supervision (released January 31, 2001). The Department of Housing and Urban Development issued a series of reports documenting high rates of subprime lending in low-income and predominantly minority communities in five cities, including Atlanta, Los Angeles, Baltimore, New York, and Chicago. See Dep't. Of Hous. And Urb. Dev., UNEQUAL BURDEN: INCOME AND RACIAL DISPARITIES IN SUBPRIME LENDING IN AMERICA (2000) available at (visited September 13,2000 ) <wysiwyg://http://www.huduser.org/ publications/fairhsg/unequal.html>. The Woodstock Institute published a similar study of subprime lending in Chicago. See Daniel ImMergluck and Marti Wiles, Two Steps Back: The Dual Mortgage Market, Predatory Lending, and the Undoing of COMMUNITY DEVELOPMENT (1999). Private attorneys are developing litigation strategies to protect their clients from predatory lending. See Odette Williamson, Protecting Elderly Homeowners from Predatory Mortgage Lenders, September-October 2000 J. POV. L. \& POL. 297. See also, Action to Draw Banks Away from Predatory Loan Market, INSIDE MORT. Compl., May 29, 2000, at 6; Dean Anason, Treasury, HUD Urge Predatory Loan Curbs, AM. BANKer, June 21, 2000, at 4; Dean Anason, 2 Agencies to Issue Plan for Curbs on Predatory Lending, AM. BANKER, June 18, 2000, at 4; Dean Anason, Fed, Justice Eye Existing Laws to Curb Predators, AM. BANKER, June 5, 2000, at 1; Dean Anason, Democrats Hit 'Predators' in Three Bills, AM. BANKER, April 13, 2000, at 1; Eric Bergquist, Industry Hits Back on Lending Abuse Laws, AM. BANKER, Jan, 26, 2001, at 1; Rob Blackwell, Fed Proposes Even Tighter Loan Scrutiny, AM. BANKER, Dec. 14, 2000, at 1; Fed Board Considers Expanding HMDA Reporting to Include Pricing, Other Loan-Term Data to Identify Predatory Loans, INSIDE MORT. COMPL., Oct. 30, 2000, at 2; Amanda Fung, Baltimore, an Anti-Predatory Lending Model, AM. BANKER, Dec. 27, 2000, at 9; Kevin 
Second, the 1999 Scorecard provides more information about individual lenders. It lists several lenders with poor lending records among low-income and minority borrowers and neighborhoods and provides information about their loan originations, market shares, and denial ratios in those communities. The Scorecard also examines the most recent performance ratings each lender with a poor lending record in at least one subject community that is a bank received under the Community Reinvestment Act (CRA). ${ }^{15}$

The Scorecard is divided into two parts. Part One examines aggregate residential real estate-related lending and conventional home

Guerrero, Brokers Blast N.Y. Proposal To Fight Predatory Lending, AM. BANKER, May 3, 2000, at 2; Kevin Guerrero, Calif., N.Y. Eye Curbing Predatory Loan Terms as Congress Watches, AM. BANKER, April 26, 2000, at 1; Kevin Guerrero, Activist Group Challenges Wells' Alaska Deal, AM. BANKER, April 18, 2000, at 3; Michele Heller, Blacks Main Subprime Target, Acorn Says, AM. BANKER, Nov. 1, 2000, at 2; HUD, Treasury Release Predatory Lending Report, June 26, 2000 Hous. DEV. REP. at 116; Illinois Governor Announces Plan to Curb Predatory Lending, January 22, 2001 Hous. DEV. REP. at 597; Image Tarnished, Delta Exits High-Cost Mortgage Market, InSIDE MORT. COMPL., Oct. 16, 2000, at 9; Robert Julavits, Citi Pledges to Address Beefs About Associates, AM. BANKER, Nov. 12, 2000, at 1; Robert Julavits and Mark Hochstein, Politics, Lawsuits Make Subprime a War Zone, AM. BANKer, June 23, 2000, at 1; Robert Julavits, Predatory Lending Issue Puts Subprime Lenders in a Bind, AM. BANKER, April 19, 2000; Bruce Lambert, Lending Crackdown Said to Fall Short, N.Y. Times, May 14, 2000, at A36; Liz Moyer, Citi Takes Steps to Quiet Critics of Associates Deal, Am. BANKeR, Nov. 8, 2000, at 1; NY Issues 'High Cost' Rule, Further Changes Proposed, INSIDE MoRT. CoMPL., July 24, 2000, at 10; Regulators Draft Joint Policy Statement on Predatory Lending, Seek Comments on List of Potentially Abusive Lending Practices, INSIDE MORT. COMPL., June 12, 2000, at 2; Subprime Lenders Dominate DC Minority Census Tracts, INSIDE MORT. COMPL., July 10, 2000, at 9; Laura K. Thompson, D.C. Anti-Predatory Bill Ist to Target Foreclosures, AM. BANKER, Dec. 7, 2000, at 6; Laura K. Thompson, D.C. Bill Would Block Predator Foreclosure, AM. BANKER, Oct. 20, 2000, at 1; Unscrupulous Lenders Reel From Two-Front Assault, INSIDE MORT. COMPL., April 17, 2000, at 8; Ways to Deny CRA Credit to Predatory Loans Under Study, INSIDE MORT. COMPL., October 30, 2000, at 4; Craig Woker, Bank Group Would Refinance Predator Victims' Loans, AM. BANKER, June 23, 2000, at 1; and Craig Woker, Chicago Weighs Halt of City Business For Banks Linked to Predatory Loans, AM. BANKER, April 24, 2000, at 1. For earlier efforts, see 1998 Scorecard at 805, n.39.

${ }^{15} 12$ U.S.C.A. $\$ \S 2901-2908$ (1989 \& Supp. 2000). The CRA states that banks have an affirmative obligation to meet the credit needs of their local communities. Id. at $\S 2901$ (a) (3). The CRA requires the four federal banking regulatory agencies to supervise bank compliance with the CRA. The relevant agency is required to evaluate a bank's record of meting community credit needs, including low- and moderate-income neighborhoods, and to take that record into account when considering a bank's application to expand its business. Id. at $\S 2903$ (2). The agency is to issue a written evaluation report about the bank's CRA performance, including one of four ratings of the bank's performance: substantial noncompliance; needs to improve; satisfactory; and outstanding. Id. at $\S 2906$. 
mortgage lending to four "subject communities" in the New York metropolitan area in 1999, the latest year for which data about such lending are available, by all lenders that are required to report such data. ${ }^{16}$ The four subject communities are minority persons, ${ }^{17}$ LMI persons, ${ }^{18}$ predominantly minority neighborhoods, ${ }^{19}$ and LMI neighborhoods. ${ }^{20}$ Part

${ }^{16}$ The Home Mortgage Disclosure Act (HMDA), 12 U.S.C.A. $\S \S 2801-2810$ (1989 \& Supp. 2000), requires lenders, including "depository institutions" and "other lending institutions," to disclose certain information about their residential real estate-related lending. Depository institutions, including banks, savings associations, and credit unions, that as of December 31,1998 had assets of at least $\$ 29$ million and a home or branch office in an MSA, were required to report under HMDA in 1999. 12 U.S.C.A. $\S \S 2802$ (2), 2803 (a) (1), 2808 (b); 12 C.F.R. $\S 203.3$ (a) (2000); Federal Reserve System, Final Rule, Regulation C (Docket No. R-1033) (December 17, 1998). In 1999, "other lending institutions" included "any person engaged for profit in the business of mortgage lending," provided they had at least $\$ 10$ million in assets or made 100 loans the previous year. 12 U.S.C.A. § 2802 (2) (B), (4); 12 C.F.R. § 203.3 (a) (2).

HMDA requires lenders to report information about four different types of residential real estate-related loans: 1) conventional home mortgage loans; 2) federally insured home mortgage loans; 3) home mortgage refinance loans; and 4) home improvement loans. 12 U.S.C.A. $\S 2803$ (b); 12 C.F.R. $\$ 203.4$ (a); 12 C.F.R. pt. 203, app. A, $\S \S$ V.A. 3-4.

HMDA also requires lenders to report whether the property that is the subject of the application has four or fewer residential units or more than four residential units. 12 C.F.R. pt. 203, app. A, $\S \S$ V.A. 4-5. If the property has four or fewer residential units, HMDA requires the lender to report whether the property is owner-occupied. 12 U.S.C.A. $\S 2803$ (b) (2); 12 C.F.R. $\S 203.4$ (a) (3).

For each of the four types of residential real-estate loans HMDA covers, lenders must report: 1) the number of applications received; 2) the race, income, and gender of each applicant; 3) the census tract in which the property that was the subject of the loan application is located; and 4) the disposition of each application, including loan originated, application denied, application approved but applicant turned down the loan, application withdrawn, or file closed because incomplete. 12 U.S.C.A. $\S 2803$ (b) (4); 12 C.F.R. $\S 203.4$ (a).

${ }^{17}$ The Scorecard defines minority persons to include all the racial categories reported under HMDA except "White." These are "American Indian or Alaskan Native," "Asian or Pacific Islander," "Black," and "Hispanic." See 12 C.F.R. pt. 203, app. A, § V.D.3 (2000).

${ }^{18}$ The Scorecard defines an LMI person the same way as the FFIEC does when it reports HMDA data: a person with an income of less than 80 percent of the MSA median income. See, e.g., Home Mortgage Disclosure Act Disclosure Statement: Explanation of Notes (visited Apr. 12, 2000) <http://www.ffiec.gov/hmda_rpt/ notes.html>. See also 12 C.F.R. $\$ 25.12$ (n) (1) (2000).

${ }^{19}$ The Scorecard defines a predominantly minority neighborhood as a census tract that has a minority population of 80 percent or greater. This definition corresponds to the way the FFIEC reports HMDA data. See, e.g., Business and Financial Statistics, 85 FED. RES. BULL. A65, tbl. 4.37 (1999).

${ }^{20}$ The Scorecard defines an LMI neighborhood the same way as the FFIEC does 
One compares changes in residential real estate-related lending in these four subject communities from 1998 to 1999 to changes in such lending in their "control communities," ${ }^{21}$ which are, respectively, White persons, UI persons, ${ }^{22}$ predominantly White neighborhoods, ${ }^{23}$ and UI neighborhoods. ${ }^{24}$ Part One includes separate "Scorecards" for residential real estate-related lending and conventional home mortgage lending that present the results of the lending comparisons in the subject and control communities. The Scorecards contain scores for various performance indicators and an overall score. Part One also analyzes subprime lending patterns in the subject communities and compares it to subprime lending in the control communities.

Part Two of the Scorecard turns its attention to the record of individual lenders in 1999. It examines the conventional home mortgage lending record in the subject communities of each of the 152 lenders in the New York metropolitan area that made at least 30 conventional home mortgage loans in the metropolitan area, assigns a score based on their record in the subject community, ranks the lenders accordingly, and identifies which lenders specialize in making subprime loans. Part Two also identifies those lenders with particularly weak records of lending in each of the subject communities and examines the CRA rating of banks

when it reports HMDA data: a census tract that has a median family income of less than 80 percent of the MSA median income. See Home Mortgage Act Disclosure Statement: Explanation of Notes, supra note 18.

${ }^{21}$ In the Scorecard, a "control community" is a community whose relevant characteristic is opposite that of the subject community. The assumption the Scorecard makes is that lenders lend in the control communities are unbridled by any of the inappropriate considerations or practices that they may be using in the subject communities, and thus changes in lending in the control communities represent the "normal" amount of change each year against which to measure annual changes in the subject communities.

${ }_{22}$ The Scorecard defines a UI person the same way as the FFIEC does when it reports HMDA data: a person with an income 120 percent or higher of the MSA median income. See Home Mortgage Disclosure Act Disclosure Statement: Explanation of Notes, supra note 18.

${ }^{23}$ In order to be consistent with the definition of a predominantly minority neighborhood, this Scorecard defines a predominantly White neighborhood as the opposite of a predominantly minority neighborhood: a census tract with a White population of 80 percent or higher.

${ }^{24}$ The Scorecard defines a UI neighborhood the same way as the FFIEC does when it reports HMDA data: a census tract with a median income 120 percent or higher of the MSA median income. See Home Mortgage Disclosure Act Disclosure Statement: Explanation of Notes, supra note 18. 
that are lenders with poor records.

\section{A. Summary of Results}

\section{Residential Real Estate-Related Lending}

*Overall Growth: In contrast to 1998 , which saw significant increases in residential real estate-related lending in all subject and control communities, the total number of residential real estate-related loan applications filed and loans originated increased in some communities and declined in others in 1999. White persons filed fewer applications, and White persons, predominantly minority neighborhoods, and LMI neighborhoods received fewer loans.

* Applications: With the exception of minority individuals, residential real estate-related application growth was greater in the control communities than in the subject communities in 1999; it was significantly greater in White and UI neighborhoods than in their corresponding subject communities. This contrasts with 1998, when residential real estate-related applications from both LMI and minority individuals outgrew applications from their control communities.

*Originations: Once again with the exception of minority individuals, residential real estate-related loan originations increased at greater rates in the control communities than in the subject communities in 1999. The difference in growth rates was especially significant in predominantly White neighborhoods (47.9 percent) compared to predominantly minority neighborhoods, where lending declined by 11.2 percent, and UI neighborhoods (31.9 percent) compared to LMI neighborhoods (-2.7 percent). This is in contrast to 1998, when residential real estate-related originations in each subject community outgrew increases in its corresponding control community.

${ }^{*}$ Denial Rate Ratios: Denial rate ratios ${ }^{25}$ for residential real estate-related loans declined for every subject community except predominantly minority neighborhoods, where they remained the same. This contrasts to 1998 , when the denial rate ratio remained the same in three subject communities and decreased in predominantly minority neighborhoods.

\footnotetext{
${ }^{25}$ See infra, note 28 , for a definition and description of denial rate ratios.
} 
*Scorecard Results: Overall, the subject communities fared slightly worse than the control communities in residential real estaterelated lending in 1999, reflected in a -1 score for the subject communities on the 1999 residential real estate-related lending Scorecard. This contrasts to 1998 , when the subject communities received a +5 score.

*Subject Communities: Among the subject communities, minority individuals fared the best, with a score of +3 , as the residential real estate-related loan applications they submitted and the loans they received increased compared to White individuals, and their denial rate ratio declined. The remaining three subject communities, in contrast, had negative scores. This contrasts with 1998, when none of the subject communities had a negative score for residential real estate-related lending.

*Prime Lending: When looking at prime lenders only, the scores on the residential real estate-related loan Scorecard do not change, meaning that the relative changes in residential real estate-related applications submitted and loans originated between the subject and control communities remain constant. What does change, however, is the degree of difference in the relative change. That is, when excluding subprime lenders, applications and lending in the control communities grew at an even faster rate than in the subject communities when including all lenders.

\section{Conventional Home Mortgage Lending}

* Overall Growth: Consistent with 1998, which saw significant increases in conventional home mortgage lending in the subject and control communities, the number of conventional home loan applications filed and loans originated increased for all communities in 1999.

*Applications: With the exception of minority individuals, conventional home mortgage loan application growth was higher in the control communities than in the subject communities. It was significantly higher in White and UI neighborhoods than in minority and LMI neighborhoods. This contrasts with 1998, when the reverse occurred, and application growth was greater for all subject communities except for minority individuals.

* Originations: Increases in conventional home mortgage loan originations were somewhat greater for minority and LMI individuals 
than White and UI individuals, respectively. In contrast, increases were much greater in White and UI neighborhoods than in predominantly minority and UI neighborhoods. This contrasts with 1998, when, except for minority individuals, conventional home mortgage lending in each subject community outgrew conventional home mortgage lending in each corresponding control community.

*Denial Rate Ratios: Denial rate ratios for conventional home mortgage loans declined for every subject community in 1999. The decline was most significant for LMI persons, for whom the denial rate ratio declined from 2.0 to 1.7 , perhaps explaining why conventional home mortgage lending to LMI persons outgrew lending to UI persons even though applications from LMI persons did not outgrow applications from UI persons. The denial rate ratio for predominantly minority neighborhoods was 1.9 , which is consistent with discrimination against minority neighborhoods.

${ }^{*}$ Scorecared Results: In contrast to their performance in the residential real estate-related lending market, the subject communities fared slightly better than the control communities in the conventional home mortgage lending market in 1999. The subject communities scored +2 on the conventional home mortgage lending Scorecard. This was not as strong, however, as 1998 , when the subject communities scored +5 on the conventional home mortgage lending Scorecard.

* Subject Communities: Among the subject communities, minority individuals scored the highest, with +3 , as the number of conventional home mortgage loan applications they submitted and the number of loans they received increased compared to Whites, and the denial rate ratio declined. LMI individuals were next, outpacing UI individuals in originations and enjoying a decline in denial rate ratio. Predominantly minority and LMI neighborhoods each scored -1 . In 1998 , only minority individuals had a negative score on the conventional home mortgage lending Scorecard.

* Prime Lending: When looking at prime lenders only, the scores on the conventional home mortgage loan Scorecard do not change, meaning that the relative changes in conventional home mortgage applications submitted and loans originated between the subject communities and control communities do not change. What does change, however, is the degree of difference in the relative change. That is, when excluding subprime lenders, application and loan growth in the control 
communities was generally slightly higher than growth in the subject communities than when including all lenders.

\section{Minority Individuals}

*Residential Real Estate-Related Lending: Among the various racial groups represented in the HMDA data, residential real estaterelated loan applications declined for Native Americans and Whites in 1999, but increased for Asians/Pacific Islanders, African-Americans, and Latinos. Loan originations declined for all groups except Latinos. Asians/Pacific Islanders, African-Americans, and Latinos outperformed Whites in applications and originations, while Native Americans did not. Denial rate ratios declined for African-Americans and Latinos, and remained the same for Native Americans and Asians/Pacific Islanders.

${ }^{*}$ Conventional Home Mortgage Lending: Among the various racial groups represented in the HMDA data, the total number of conventional home mortgage loan applications and loan originations increased in 1999. The denial rate ratio declined for all subject communities except Asians/Pacific Islanders, for whom it remained the same. Overall, Native Americans, Asians/Pacific Islanders, and Latinos outperformed Whites, while African-Americans did not. Denial rate ratios for Native Americans and African-Americans, despite declining, are consistent with discrimination against those groups.

\section{Subprime Lending}

*Subprime lending was a much greater part of residential real estate-related and conventional home mortgage lending in the subject communities than in the control communities. Frequently, the proportion of subprime loan applications and loan originations in the subject communities was twice as high as in control communities.

*Subprime residential real estate-related lending declined in all communities in 1999 except minority and LMI individuals. Subprime conventional home mortgage lending declined in every community. Overall, declines were greater in the control communities than in the corresponding subject communities.

*Applications for residential real estate-related loans to subprime lenders increased in 1999 for all communities except UI persons, where they declined slightly. Application growth was greater in the subject 
communities than in the control communities except for LMI neighborhoods, where growth was slightly lower than in UI neighborhoods. Applications for conventional home mortgage loans submitted to subprime lenders declined for all communities except LMI persons in 1999, and the decline in control communities was greater than the decline in subject communities, except for minority individuals.

\section{Individual Lenders}

*Individual subprime lenders as a whole outperformed all other lenders as a whole in the subject communities; only one of the 19 subprime and manufactured home lenders represented scored less than 0 on the individual lender Scorecard.

*Fifty-six lenders had a poor lending record in at least one subject community. This means that the percentage of conventional home mortgage loans the lender originated in that subject community was no more than half of the metropolitan area average, the lender's market share in the subject community was no more than half of the its share in the control community, and the lender's denial rate ratio was equal to or greater than the metropolitan area denial rate ratio.

* Many lenders that had a poor lending record shared one or more of the following characteristics: 28 made no loans at all in at least one subject community; 7 were among the top 25 conventional home mortgage loan originators; 22 had a poor lending record in more than one subject community; and, 34 were banks subject to the Community Reinvestment Act ("CRA").

*Of the 34 banks with a poor lending record in at least one subject community, none of these banks had less than a satisfactory rating on their most recent CRA examination report. Twelve of the banks were not even evaluated for their CRA performance in the New York metropolitan area because they did not include the metropolitan area within their CRA assessment area. Eighteen of the banks did not make a loan in at least one subject community. 


\section{RESIDENTIAL REAL ESTATE-RELATED LENDING AND CONVENTIONAL Home Mortgage Lending IN THE NEW York METROPOLITAN AREA, 1998-1999}

\section{A. Residential Real Estate-Related Lending}

\section{Methodology}

This section examines aggregate residential real estate-related lending by all lenders in the New York metropolitan area who. were required to report such lending in 1999 and compares it to $1998 .{ }^{26}$ Residential real estate-related lending includes government-insured home mortgage loans, conventional home mortgage loans, home mortgage refinance loans, home improvement loans, and multi-family home purchase loans. This section measures residential real estate-related lending in the four subject communities and compares it to lending in the control communities.

The Scorecard employs three indicators to evaluate changes in residential real estate-related lending in the four subject communities in New York from 1998 to 1999:

*Comparative percentage change in total residential real estate-related loan applications submitted: This indicator compares the percentage change in the total number of residential real estate-related loan applications each subject community submitted from 1998 to 1999 to the percentage change in each subject community's control community. ${ }^{27}$

*Comparative percentage change in total residential real estate-related loans originated: This indicator compares the percentage change in the total number of

${ }^{26}$ The source of the lending data in the Scorecard is the Federal Financial Institutions Examination Council (FFIEC). The FFIEC makes HMDA data available in various ways, including through its website, http://www.ffiec.gov.

${ }^{27}$ The number of applications a community submits is a good indicator of lenders' efforts to market loans to that community and has a strong relation to the number of loans the community receives. See Marsico, supra note 6, at 525-26. 
residential real estate-related loan originations in each subject community from 1998 to 1999 to the percentage change in each subject community's control community.

*Change in denial rate ratio: This indicator measures the change in the real estate-related loan application denial rate ratio in each subject community from 1998 to $1999 .{ }^{28}$

The Scorecard applies these three indicators to the four subject communities, resulting in twelve indicators to evaluate residential real estate-related lending in the subject communities in the New York metropolitan area in 1999:

\section{Percentage Change in Applications Submitted, 1998-1.999}

1. Minority/White individuals

2. LMI/UI individuals

3. Predominantly minority/Predominantly White neighborhoods

4. LMI/UI neighborhoods

Percentage Change in Loans Originated, 1998-1999

5. Minority/White individuals

6. LMI/UI individuals

7. Predominantly minority/Predominantly White neighborhoods

8. LMI/UI neighborhoods

Change in Denial Rate Ratio, 1998-1999

9. Minority/White applicants

10. LMI/UI applicants

11. Predominantly minority/Predominantly White neighborhoods

12. LMI/UI neighborhoods

${ }^{28}$ A denial rate ratio is a way of measuring lenders' relative treatment of applications from a subject community to its control community. See id. at 488 . The Scorecard derives the denial rate ratio by dividing the denial rate for applications from a subject community by the denial rate for applications from its control community. For example, if lenders deny 30 percent of applications from minority persons and 15 percent of applications from Whites, the denial rate ratio is $2(30 / 15=2)$. 
The Scorecard assigns a score to each of the twelve indicators. There are three possible scores: " +1, ," -1 ," or "0." The score for applications and loan originations is based on the percentage change in the number of applications from and loan originations to a subject community from 1998 to 1999 relative to the percentage change in its control community. If the percentage increase in the number of applications from or loan originations to a subject community was higher (or the percentage decrease was lower) than its control community, the score is +1 . If the reverse occurred, the score is -1 . If there was no difference, the score is 0 . For the denial rate ratio, if the denial rate ratio in a subject community decreased from 1998 to 1999 , the score is +1 . An increased denial rate ratio is -1 , and no change in the denial rate ratio is 0 . For example, if the number of residential real estate-related loans originated to minority individuals increased 10 percent from 1998 to 1999 and the number of residential real estate-related loans originated to White individuals increased 8 percent, the score is +1 for that indicator. If the denial rate ratio for minorities decreased from 1.9 to 1.8 , the score is also +1 . The Scorecard tabulates the score for all the indicators to derive a total score for residential real estate-related lending in the New York metropolitan area in 1999. 


\section{Results}

Table One is the "Scorecard" for residential real estate-related lending in 1999 in the New York metropolitan area:

Table One

SCORECARD

RESIDENTIAL REAL ESTATE-RELATED LENDING

NEW YORK METROPOLITAN AREA

1998-1999

\begin{tabular}{|l|c|c|c|c|}
\hline $\begin{array}{c}\text { SUBJECT } \\
\text { COMMUNITY }\end{array}$ & APPLICATIONS & ORIGINATIONS & $\begin{array}{c}\text { DENIAL RATE } \\
\text { RATIO }\end{array}$ & TOTAL \\
\hline $\begin{array}{l}\text { Minority } \\
\text { Individuals }\end{array}$ & +1 & & & +1 \\
\hline LMI Individuals & -1 & -1 & +1 & +3 \\
\hline $\begin{array}{l}\text { Predominantly } \\
\text { Minority }\end{array}$ & & -1 & 0 & -1 \\
\hline Neighborhoods & -1 & & & -2 \\
\hline LMI & & -1 & +1 & -1 \\
\hline Neighborhoods & -1 & -2 & +3 & -1 \\
\hline Total & -2 & & & \\
\hline
\end{tabular}

As more fully elaborated in Tables Two, Three and Four, residential real estate-related loan applications filed and loans originated increased for some communities from 1998 to 1999 and decreased for others. The overall score for residential real estate-related lending in the subject communities is -1 , meaning that overall the subject communities fared slightly worse than the control communities. Among the subject communities, minority individuals fared the best, with a score of +3 . The remaining subject communities had negative scores. This contrasts with 1998, when residential real estate-related loan applications and originations were up for all communities, the score for the subject communities was +5 , and none of the subject communities individually had a negative score.

In 1999, subprime lenders were more active in the residential real estate-related loan market in the subject communities than in the control communities, although not enough to change the results of the Scorecard. Subprime residential real estate-related loan originations declined in most 
control and subject communities and declined as a percentage of all originations in each community. However, subprime lending remained a much more significant part of residential real estate-related lending in the subject communities than in the control communities.

\section{a. Applications}

Table Two shows the total number of residential real estaterelated loan applications each subject and control community submitted in 1998 and 1999, the percentage increase, and the score: ${ }^{29}$

Table Two

RESIDENTIAL REAL ESTATE-RELATED LENDING APPLICATIONS RECEIVED AND PERCENTAGE CHANGE NEW YORK METROPOLITAN AREA 1998-1999

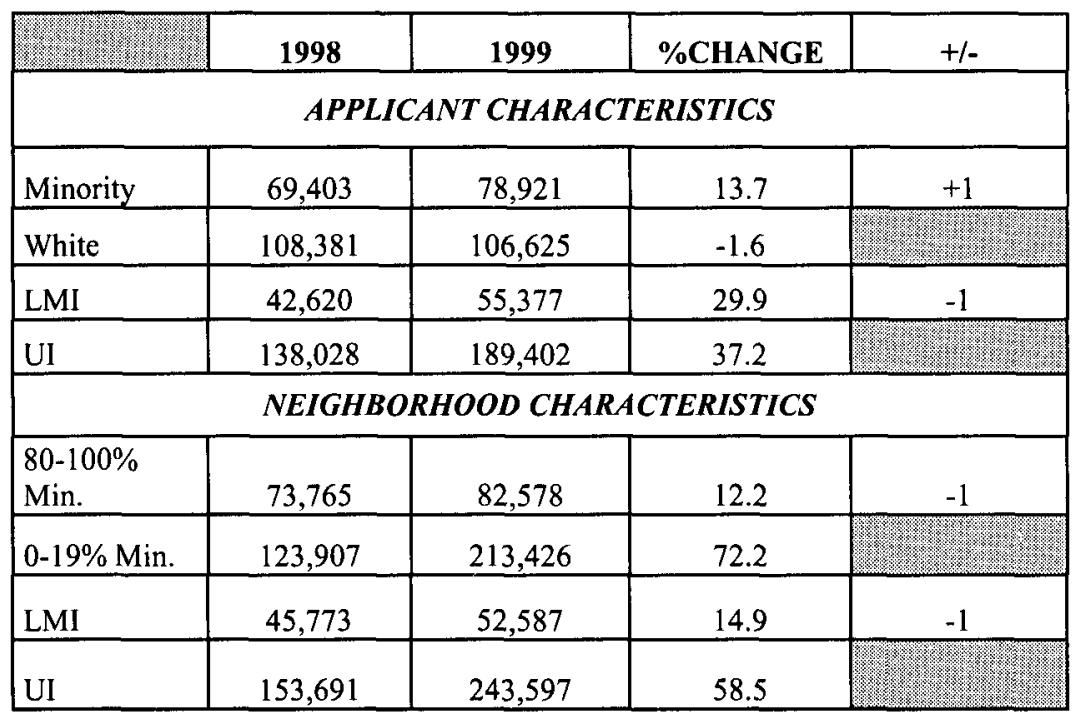

Table Two shows that applications for residential real estaterelated loans from all communities - except white individuals increased significantly. Percentage increases ranged from 12.2 percent for predominantly minority neighborhoods to 72.2 percent for

${ }^{29}$ All percentages, denial rates, and denial rate ratios in the Scorecard are rounded to the nearest tenth. 
predominantly white neighborhoods. The only subject community that outgrew its control community was minority individuals.

Table Two (A) examines the same criteria as Table Two but only includes prime lenders: ${ }^{30}$

\author{
Table Two (A) \\ RESIDENTIAL REAL ESTATE-RELATED LENDING \\ APPLICATIONS RECEIVED AND PERCENTAGE CHANGE \\ PRIME LENDERS ONLY \\ NEW YORK METROPOLITAN AREA \\ 1998-1999
}

\begin{tabular}{||l|c|c|c|}
\hline \multirow{4}{*}{} & 1998 & 1999 & \% CHANGE \\
\hline Minority & APPLICANT CHARACTERISTICS \\
\hline White & 51,209 & 57,173 & 11.6 \\
\hline LMI & 92,617 & 90,526 & -2.3 \\
\hline UI & 23,396 & 26,666 & 14.0 \\
\hline \multicolumn{4}{|c|}{ NEIGHBORHOOD CHARACTERISTICS } \\
\hline $80-100 \%$ Min. & 38,172 & 37,375 & 61.6 \\
\hline $0-19 \%$ Min. & 75,572 & 154,378 & -2.1 \\
\hline LMI & 25,723 & 27,675 & 104.3 \\
\hline UI & 89,813 & 164,078 & 7.6 \\
\hline
\end{tabular}

${ }^{30}$ In this and all subsequent tables that distinguish between prime and subprime lenders, the Scorecard relies on the work of Randall M. Scheessele, a researcher with the Department of Housing and Urban Development, to identify subprime lenders. See Randall M. Scheessele, 1999 HUD SUBPRIME AND MODIFIEd HOME LENDERS, at tbl. A.1 (2000) available at (visited August 23, 2000) <wysiwyg://53/http://www.huduser. org/datasets/manu.html>; Randall M. Scheessele, 1998 HMDA HIGHLIGHTS, at tbl. D.5b (Dep't of Hous. \& Urban Dev., Office of Pol'y Dev. \& Research, Working Paper No. HF009) (1999). Scheessele identifies seventeen subprime and two manufactured home lenders in the New York metropolitan area in 1999 and twenty subprime and two manufactured home lenders in 1998. Manufactured home lenders specialize in making loans to purchase homes that are manufactured off-site and assembled on-site. For purposes of analyzing subprime lending patterns and the record of individual subprime lenders, the Scorecard includes these manufactured home lenders with subprime lenders. As with subprime lenders, manufactured home lenders primarily operate in LMI and minority communities. See Canner \& Passmore, supra note 9, at 709, 718, 721. Manufactured home loans are deemed riskier than other home mortgage loans and borrowers tend to have weaker credit histories and fewer resources. Id. at 713 . 
Comparing Table Two (A) with Table Two shows that the relative growth trends in applications for residential real estate-related loans between the subject and control communities remain constant when excluding subprime lenders; thus the results in the application section of the residential real-estate related Scorecard do not change. However, the comparison between Table Two (A) and Table Two also shows that percentage increases in applications in the subject communities were smaller when excluding subprime lenders than when including them; in fact residential real estate-related loan applications from predominantly minority neighborhoods went from a 12.2 percent growth rate to a 2.1 percent decline when excluding subprime lenders. In contrast, with the exception of white individuals, growth in the control communities increased at greater rates when excluding subprime lenders.

Table Two (B), in contrast, examines the same criteria as Table Two, but includes subprime lenders only:

Table Two (B)

RESIDENTIAL REAL ESTATE-RELATED LENDING APPLICATIONS RECEIVED AND PERCENTAGE CHANGE SUBPRIME LENDERS ONLY

NEW YORK METROPOLITAN AREA

1998-1999

\begin{tabular}{|l|c|c|c||}
\hline \multicolumn{4}{|c|}{ APPLICANT CHARACTERISTICS } \\
\hline Minority & 18,194 & 21,748 & \% CHANGE \\
\hline White & 15,764 & 16,099 & 19.5 \\
\hline LMI & 19,224 & 28,711 & 2.1 \\
\hline UI & 54,615 & 54,586 & 49.3 \\
\hline & NEIGHBORHOOD CHARACTERISTICS \\
\hline $80-100 \%$ Min. & 35,593 & 45,383 & -0.1 \\
\hline 0-19\% Min. & 48,335 & 59,048 & 27.5 \\
\hline LMI & 20,050 & 24,912 & 24.2 \\
\hline UI & 63,878 & 79,519 & 24.5 \\
\hline
\end{tabular}


Table Two (B) shows that all subject and control communities except UI individuals submitted more applications to subprime lenders in 1999 than 1998. The increases were markedly different for minority individuals (19.5 percent) and White individuals (2.1 percent) and LMI individuals (49.3 percent) and UI individuals (-0.1 percent). The growth rates were roughly equal for predominantly minority and White neighborhoods; in fact, growth in UI neighborhoods was slightly higher.

Finally, Table Two (C) shows the percentage of all applications each subject and control community submitted to subprime lenders in 1998 and 1999 and the percentage change:

Table Two (C)

RESIDENTIAL REAL ESTATE-RELATED LENDING

PERCENTAGE OF APPLICATIONS TO SUBRIME LENDERS

AND PERCENTAGE CHANGE

NEW YORK METROPOLITAN AREA

1998-1999

\begin{tabular}{|l|c|c|c|}
\hline \hline 4.07 & 1998 & 1999 & \% CHANGE \\
\hline \multicolumn{4}{|c|}{ APPLICANT CHARACTERISTICS } \\
\hline Minority & 26.2 & 27.6 & 5.3 \\
\hline White & 14.5 & 15.1 & 4.1 \\
\hline LMI & 45.1 & 51.8 & 14.9 \\
\hline UI & 39.6 & 28.8 & -27.3 \\
\hline \multicolumn{4}{|c|}{ NEIGHBORHOOD CHARACTERISTICS } \\
\hline 80-100\% Min. & 48.3 & 54.8 & 13.6 \\
\hline 0-19\% Min. & 39.0 & 27.7 & -29.0 \\
\hline LMI & 43.8 & 47.4 & 8.2 \\
\hline UI & 41.6 & 32.6 & -21.6 \\
\hline
\end{tabular}

Table Two (C) shows that, except for minority individuals, the subject communities submitted applications to subprime lenders at significantly higher rates than their control communities. In fact, more 
than one-half of the applications from LMI individuals ( 51.8 percent) and predominantly minority neighborhoods (55 percent) and nearly half of the applications from LMI neighborhoods (47.4 percent) were to subprime lenders. The percentages increased for all subject communities from 1998 to 1999, and declined for all control communities except Whites.

\section{b. Originations}

Table Three shows the total number of residential real estaterelated loans originated in each subject community and control community in 1998 and 1999, the percentage change, and the score:

Table Three

RESIDENTIAL REAL ESTATE-RELATED LENDING

LOANS ORIGINATED AND PERCENTAGE CHANGE

NEW YORK METROPOLITAN AREA

1998-1999

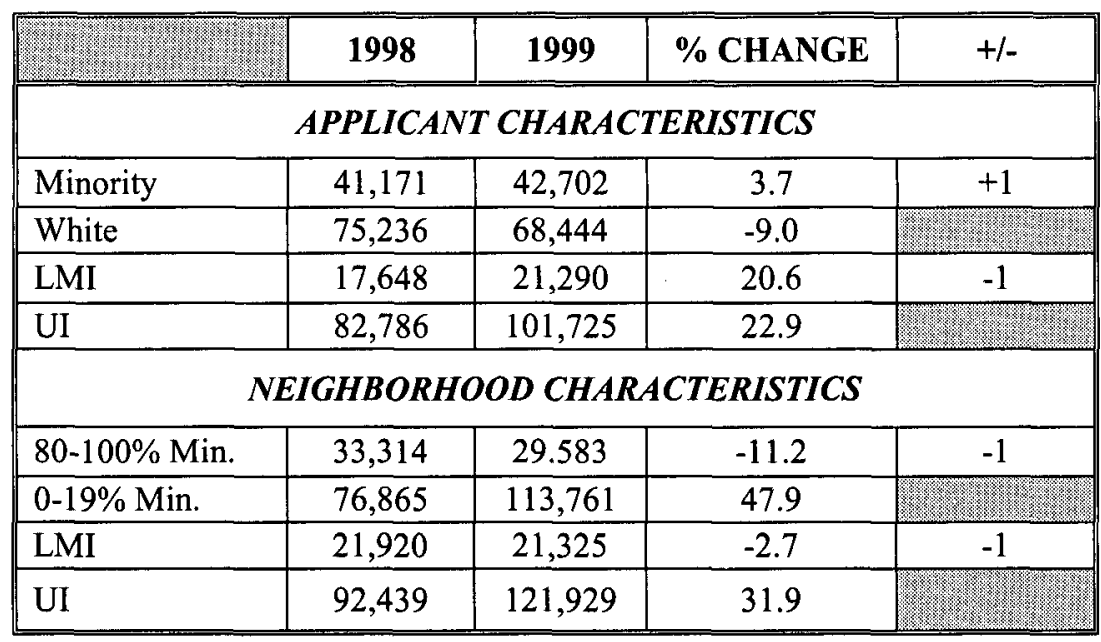

According to Table Three, residential real estate-related lending to minority and LMI persons, UI persons, and UI and White neighborhoods grew in 1999, while lending to Whites and predominantly minority and LMI neighborhoods declined. Growth in loan originations to minorities outpaced lending to Whites, which actually declined, but 
each of the other control communities outgrew its corresponding subject community.

Table Three (A) examines the same criteria as Table Three but includes prime lenders only:

Table Three (A)

RESIDENTIAL REAL ESTATE-RELATED LENDING

LOANS ORIGINATED AND PERCENTAGE CHANGE

PRIME LENDERS ONLY

NEW YORK METROPOLITAN AREA

1998-1999

\begin{tabular}{|l|c|c|c|}
\hline & 1998 & 1999 & \% CHANGE \\
\hline \multicolumn{4}{|c|}{ APPLICANT CHARACTERISTICS } \\
\hline Minority & 35,268 & 36,786 & 4.3 \\
\hline White & 66,893 & 64,167 & -4.1 \\
\hline LMI & 13,178 & 16,300 & 23.7 \\
\hline UI & 69,754 & 89,983 & 29.0 \\
\hline \multicolumn{4}{|c|}{ NEIGHBORHOOD CHARACTERISTICS } \\
\hline $80-100 \%$ Min. & 22,420 & 21,888 & -2.4 \\
\hline $0-19 \%$ Min. & 63,053 & 103,924 & 64.8 \\
\hline LMI & 15,793 & 17,270 & 9.4 \\
\hline UI & 73,860 & 108,542 & 47.0 \\
\hline
\end{tabular}

Comparing Table Three (A) with Table Three shows that the relative growth trends in residential real estate-related loan originations between the subject and control communities remain constant when excluding subprime lenders; thus the results on the origination section of the Scorecard do not change. The comparison between Table Three (A) and Table Three also shows that increases in originations were greater and decreases were smaller in all communities when excluding subprime lenders. 
Table Three (B), in contrast, examines the same criteria as Table Three, but includes subprime lenders only:

Table Three (B)

RESIDENTIAL REAL ESTATE-RELATED LENDING

LOANS ORIGINATED AND PERCENTAGE CHANGE

SUBPRIME LENDERS ONLY

NEW YORK METROPOLITAN AREA

1998-1999

\begin{tabular}{||l|c|c|c||}
\hline \multicolumn{4}{|c|}{ APPLICANT CHARACTERISTICS } \\
\hline Minority & 5,903 & 5,916 & \% CHANGE \\
\hline White & 8,343 & 4,277 & 0.2 \\
\hline LMI & 4,470 & 4,990 & -48.7 \\
\hline UI & 13,032 & 11,742 & 11.6 \\
\hline & NEIGHBORHOOD CHARACTERISTICS & -9.9 \\
\hline $80-100 \%$ Min. & 10,894 & 7,695 & -29.4 \\
\hline 0-19\% Min. & 13,812 & 9,747 & -29.4 \\
\hline LMI & 6,127 & 4,055 & -33.8 \\
\hline UI & 18,579 & 13,387 & -27.9 \\
\hline
\end{tabular}

Table Three (B) shows that subprime lenders originated fewer residential real estate-related loans in six of the eight communities depicted in 1999 than in 1998. There was a very slight increase in originations to minority individuals and originations to LMI persons increased 11.6 percent. 
Finally, Table Three (C) shows the percentage of all originations subprime lenders made in each community in 1998 and 1999 and the percentage change:

Table Three (C)

RESIDENTIAL REAL ESTATE-RELATED LENDING

PERCENTAGE OF LOANS ORIGINATED BY SUBPRIME LENDERS AND

PERCENTAGE CHANGE

NEW YORK METROPOLITAN AREA

1998-1999

\begin{tabular}{|c|c|c|c|}
\hline 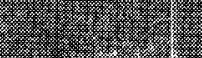 & 1998 & 1999 & \% CHANGE \\
\hline \multicolumn{4}{|c|}{ APPLICANT CHARACTERISTICS } \\
\hline Minority & 14.3 & 13.9 & -2.8 \\
\hline White & 11.1 & 6.2 & -44.1 \\
\hline LMI & 25.3 & 23.4 & -7.5 \\
\hline UI & 15.7 & 11.5 & -26.8 \\
\hline \multicolumn{4}{|c|}{ NEIGHBORHOOD CHARACTERISTICS } \\
\hline $80-100 \% \mathrm{Min}$. & 32.7 & 26.0 & -20.5 \\
\hline 0-19\% Min. & 18.0 & 8.6 & -52.2 \\
\hline LMI & 28.0 & 19.0 & -32.1 \\
\hline UI & 20.1 & 11.0 & -45.3 \\
\hline
\end{tabular}

Table Three (C) shows that subprime lenders originated residential real estate-related loans in the subject communities at significantly higher rates than in their control communities; generally the rates were approximately twice as high. The percentage of subprime originations decreased for all communities in 1999, and again, the rate of decrease was significantly higher in the control communities. 


\section{c. Denial rate ratios}

Table Four details changes in denial rate ratios. ${ }^{31}$ It depicts the denial rates and denial rate ratios for each subject community in 1998 and 1999 and the score:

Table Four

RESIDENTIAL REAL ESTATE-RELATED LENDING

DENIAL RATE RATIOS

NEW YORK METROPOLITAN AREA

1998-1999

\begin{tabular}{|c|c|c|c|c|c|}
\hline 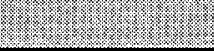 & \multicolumn{2}{|c|}{1998} & \multicolumn{2}{|c|}{1999} & $+/-$ \\
\hline & $\begin{array}{l}\text { DENIAL } \\
\text { RATE }\end{array}$ & $\begin{array}{c}\text { DENIAL } \\
\text { RATE } \\
\text { RATIO }\end{array}$ & $\begin{array}{l}\text { DENIAL } \\
\text { RATE }\end{array}$ & $\begin{array}{c}\text { DENIAL } \\
\text { RATE } \\
\text { RATIO }\end{array}$ & \\
\hline \multicolumn{6}{|c|}{ APPLICANT CHARACTERISTICS } \\
\hline Minority & 19.0 & 1.5 & 20.3 & 1.4 & +1 \\
\hline LMI & 27.3 & 1.8 & 28.7 & 1.6 & +1 \\
\hline \multicolumn{6}{|c|}{ NEIGHBORHOOD CHARACTERISTICS } \\
\hline $80-100 \%$ Min. & 22.6 & 1.5 & 27.7 & 1.5 & 0 \\
\hline LMI & 21.8 & 1.4 & 26.3 & 1.3 & +1 \\
\hline
\end{tabular}

According to Table Four, the denial rate ratio decreased for LMI applicants and neighborhoods and minority applicants and remained the same for minority persons. Although not depicted in Table Four, the denial rate ratio for subprime lenders was lower than for all lenders combined, at 1.2 for minority and LMI individuals and 1.1 for

${ }^{31}$ As a reminder, the denial rate ratio is the denial rate for residential real estaterelated loan applications in a subject community divided by the denial rate in its control community. For example, if the denial rate for predominantly minority neighborhoods is 20 percent and the denial rate for White neighborhoods is 10 percent, the denial rate ratio is 2 . 
predominantly minority and LMI neighborhoods. Denial rates in the subject communities, however, were higher for subprime lenders than all lenders combined, at 27 percent for minorities, 34 percent for LMI persons, 33 percent for predominantly minority neighborhoods, and 34 percent for LMI neighborhoods.

\section{d. Minority individuals}

Focusing next on one of the subject communities - minority individuals - HMDA data is presented so it is possible to divide minority individuals into four sub-groups: Native Americans; Asians/Pacific Islanders; African-Americans; and Latinos. It is also possible to compare lending to these individual minority groups to lending to Whites, and thus to apply each of the indicators for evaluating residential real estate-related lending to each of these four groups. The results are depicted in Table Five: 


\author{
Table Five \\ RESIDENTIAL REAL ESTATE-RELATED LENDING \\ RACE OF APPLICANT \\ NEW YORK METROPOLITAN AREA \\ 1998-1999
}

\begin{tabular}{|c|c|c|c|c|c|}
\hline & 1998 & \multicolumn{2}{|r|}{1999} & \%CHANGE & $+/-$ \\
\hline \multicolumn{6}{|c|}{ APPLICATIONS RECEIVED } \\
\hline Native Americans & 1,081 & \multicolumn{2}{|r|}{1,030} & -4.7 & -1 \\
\hline Asians/Pacific Islanders & 14,599 & \multicolumn{2}{|r|}{14,979} & 2.6 & +1 \\
\hline African-Americans & 35,917 & \multicolumn{2}{|r|}{40,385} & 12.4 & +1 \\
\hline Latinos & 17,806 & \multicolumn{2}{|r|}{22,527} & 26.5 & +1 \\
\hline Whites & 108,381 & \multicolumn{2}{|r|}{106,625} & -1.6 & 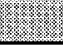 \\
\hline \multicolumn{6}{|c|}{ LOANS ORIGINATED } \\
\hline Native Americans & 572 & \multicolumn{2}{|c|}{489} & -14.5 & -1 \\
\hline Asians/Pacific Islanders & 10,324 & \multicolumn{2}{|r|}{9.909} & -4.0 & +1 \\
\hline African-Americans & 19,866 & \multicolumn{2}{|r|}{19,489} & -1.9 & +1 \\
\hline Latinos & 10,409 & \multicolumn{2}{|r|}{12,815} & 23.1 & +1 \\
\hline Whites & 75,236 & \multicolumn{2}{|r|}{68,444} & -9.0 & 102 \\
\hline & \multicolumn{4}{|c|}{ DENIAL RATE RATIO } & \\
\hline 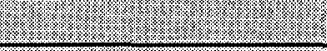 & \multicolumn{2}{|c|}{1998} & \multicolumn{2}{|c|}{1999} & \\
\hline (1) & $\begin{array}{c}\text { DENIAL } \\
\text { RATE } \\
\end{array}$ & $\begin{array}{l}\text { DENIAL } \\
\text { RATE } \\
\text { RATIO } \\
\end{array}$ & $\begin{array}{c}\text { DENIAL } \\
\text { RATE }\end{array}$ & \begin{tabular}{|c|} 
DENIAL \\
RATE \\
RATIO \\
\end{tabular} & $\sqrt{12}$ \\
\hline Native Americans & 16.1 & 1.3 & 19.1 & 1.3 & 0 \\
\hline Asians/Pacific Islanders & 12.3 & 1.0 & 13.9 & 1.0 & 0 \\
\hline African-Americans & 21.2 & 1.7 & 23.6 & 1.6 & +1 \\
\hline Latinos & 19.3 & 1.5 & 18.9 & 1.3 & +1 \\
\hline
\end{tabular}

Of the groups depicted in Table Five, Whites and Native Americans fared the worst, losing applications and loans. Latinos fared the best, gaining applications and loans and declining in denial rate ratio. African-Americans and Asians gained in applications over Whites but lost loans, although not as significantly as Whites.

Among the groups depicted in Table Five, there were wide disparities in the percentage of applications they submitted to and loans 
they received from subprime lenders. These are depicted in Table Five (A):

Table Five (A)

PERCENTAGE OF RESIDENTIAL REAL ESTATE-RELATED

LOAN APPLICATIONS SUBMITTED TO AND LOANS ORIGINATED BY

SUBPRIME LENDERS BY RACIAL GROUP

NEW YORK METROPOLITAN AREA

1999

\begin{tabular}{|l|c|c|}
\hline \multicolumn{1}{|c|}{ RACE } & APPLICATIONS & ORIGINATIONS \\
\hline Native American & 37.0 & 18.4 \\
\hline Asian/Pacific Islander & 9.2 & 3.2 \\
\hline African-American & 37.3 & 22.2 \\
\hline Latino & 21.9 & 9.3 \\
\hline White & 15.1 & 6.2 \\
\hline
\end{tabular}

Table Five(A) shows that African-Americans received nearly one quarter of all of their residential real estate-related loans from subprime lenders. This stands in sharp contrast to Asians/Pacific Islanders and Whites, who received 3.2 percent and 6.2 percent, respectively, of their residential real estate-related loans from subprime lenders.

\section{e. Conclusion}

In conclusion, growth in residential real estate-related lending was mixed for the subject and control communities in the metropolitan area in 1999 and the subject communities fared slightly worse than the subject communities, resulting in an overall score for the control communities of -1 . Among the subject communities, minority individuals had the only positive score at +1 ; among minority individuals, Latinos fared best. Subprime lenders were significantly more active in the subject communities than the control communities. Although subprime originations declined relative to all originations in all communities under study, subprime lending still remains a much more significant part of the lending in the subject communities than in the control communities. 


\section{B. Conventional Home Mortgage Lending}

\section{Methodology}

This section examines one type of loan covered by HMDA: conventional home mortgage loans. ${ }^{32}$ This section evaluates aggregate conventional home mortgage lending in the metropolitan area in 1999 in the four subject communities according to the same three indicators the previous section used to analyze all residential real estate-related lending. Applying these three indicators to the four subject communities yields the same twelve indicators used in the previous section.

\section{Results}

Table Six is the "Scorecard" for conventional home mortgage lending in 1999 in the New York metropolitan area:

Table Six

CONVENTIONAL HOME MORTGAGE LENDING SCORECARD NEW YORK METROPOLITAN AREA 1998-1999

\begin{tabular}{|l|c|c|c|c|}
\hline \multicolumn{1}{|c|}{$\begin{array}{c}\text { SUBJECT } \\
\text { COMMUNITY }\end{array}$} & APPLICATIONS & ORIGINATIONS & $\begin{array}{c}\text { DENIAL RATE } \\
\text { RATIO }\end{array}$ & TOTAL \\
\hline Minority Individuals & +1 & +1 & +1 & +3 \\
\hline LMI Individuals & -1 & +1 & +1 & +1 \\
\hline $\begin{array}{l}\text { Predominantly } \\
\text { Minority } \\
\text { Neighborhoods }\end{array}$ & -1 & & & -1 \\
\hline LMI Neighborhoods & -1 & -1 & +1 & -1 \\
\hline Total & -2 & -1 & +4 & +2 \\
\hline
\end{tabular}

${ }^{32}$ The Scorecard examines conventional home mortgage lending in particular because it is a "bellwether" loan. A conventional home mortgage loan represents a significant financial stake for the lender and borrower. See Canner \& Passmore, supra note 9, at 719. Promoting homeownership - especially among minorities - is a significant national social policy goal. See Dedman, supra note 9 . Finally, the demand for conventional home mortgage loans compared to other loans in the New York metropolitan area was relatively heavy in 1999. Applications for conventional home mortgage loans constituted 32.4 percent of all HMDA-covered loan applications in the metropolitan area in 1999, the second highest percentage. The other percentages were federally insured -3.9 , refinance - 50.5, home improvement -11.5 , and multi-family -1.7 . 
As more fully elaborated in Tables Seven, Eight, and Nine, the number of conventional home mortgage loan applications filed and loans originated increased for all communities in 1999, as they did in 1998. The score for conventional home mortgage lending in the subject communities is +2 , meaning that generally the subject communities fared better in the conventional home mortgage loan market than the control communities in 1999, as they did in 1998, although the score in 1998 was +5 .

Among the subject communities, minority individuals fared the best, scoring +3 . Application and lending growth was higher than for Whites, and the denial rate ratio declined. LMI individuals were next, at +1 . Application growth was slower than for UI individuals, but originations grew at a greater rate and the denial rate ratio declined. Predominantly minority and LMI neighborhoods each scored -1 . Applications and originations grew more slowly than in their control communities, but the denial rate ratio declined.

As with residential real estate-related lending, subprime lenders were more active in the conventional home mortgage lending market in the subject communities than in the control communities in 1999, although not enough to change the results of the Scorecard. Subprime conventional home mortgage loan originations declined, and declined as a percentage of all conventional home mortgage loan originations in all subject and control communities in 1999, but the declines were generally greater in the control communities. Additionally, subprime lending constituted a larger portion of all conventional home mortgage lending in the subject communities than in the control communities. 


\section{a. Applications}

Table Seven shows the total number of conventional home mortgage loan applications each subject community and control community submitted in 1998 and 1999, the percentage increase, and the score:

Table Seven

CONVENTIONAL HOME MORTGAGE LENDING

APPLICATIONS RECEIVED AND PERCENTAGE CHANGE

NEW YORK METROPOLITAN AREA

1998-1999

\begin{tabular}{|c|c|c|c|c|}
\hline 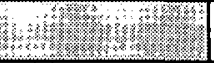 & 1998 & 1999 & $\%$ CHANGE & $+/-$ \\
\hline \multicolumn{5}{|c|}{ APPLICANT CHARACTERISTICS } \\
\hline Minority & 23,889 & 27,635 & 15.7 & +1 \\
\hline White & 46,945 & 51,263 & 9.2 & $\sqrt{1278}$ \\
\hline LMI & 10,084 & 13,704 & 35.9 & -1 \\
\hline UI & 52,627 & 74,180 & 40.9 & \\
\hline \multicolumn{5}{|c|}{ NEIGHBORHOOD CHARACTERISTICS } \\
\hline $80-100 \% \mathrm{Min}$. & 12,683 & 13,713 & 8.1 & -1 \\
\hline $0-19 \%$ Min. & 47,612 & 82,209 & 72.7 & 17 \\
\hline LMI & 9,482 & 10,971 & 15.7 & -1 \\
\hline UI & 56,775 & 84,951 & 49.6 & 80: \\
\hline
\end{tabular}

Table Seven shows that total applications increased for all communities. Percentage increases ranged from 8.1 percent for minority neighborhoods to 72.7 percent for White neighborhoods. Growth in applications from minorities was greater than for Whites, but application growth was slower in the remaining three subject communities than in their control communities. 
Table Seven (A) examines the same criteria as Table Seven but includes prime lenders only:

Table Seven (A)

CONVENTIONAL HOME MORTGAGE LENDING

APPLICATIONS RECEIVED AND PERCENTAGE CHANGE

PRIME LENDERS ONLY

NEW YORK METROPOLITAN AREA

1998-1999

\begin{tabular}{|c|c|c|c|}
\hline (2) & 1998 & 1999 & $\%$ CHANGE \\
\hline \multicolumn{4}{|c|}{ APPLICANT CHARACTERISTICS } \\
\hline Minority & 19,280 & 24,235 & 25.7 \\
\hline White & 43,114 & 48,959 & 13.6 \\
\hline LMI & 7,821 & 11,246 & 43.8 \\
\hline UI & 44,289 & 67,328 & 52.0 \\
\hline \multicolumn{4}{|c|}{ NEIGHBORHOOD CHARACTERISTICS } \\
\hline $80-100 \%$ Min. & 7,789 & 9,532 & 22.4 \\
\hline $0-19 \%$ Min. & 38,298 & 76,053 & 98.6 \\
\hline LMI & 6,048 & 8,015 & 32.5 \\
\hline UI & 46,001 & 77,570 & 68.6 \\
\hline
\end{tabular}

Table Seven (A) shows significant growth in conventional home mortgage loans applications from all communities under study when excluding subprime lenders; except for LMI persons, the growth rate was greater than when subprime lenders were included. Comparing Table Seven (A) with Table Seven also shows that the relative growth trends in applications between the subject and control communities remain 
constant when excluding suprime lenders; thus the results on the application portion of the conventional home mortgage lending Scorecard do not change when excluding subprime lenders. With the exception of minority and white individuals, the growth rate was higher in control communities than subject communities; the rate was significantly higher in predominantly white and UI communities than in their corresponding subject communities.

Table Seven (B), in contrast, also examines the same criteria as Table Seven, but includes only subprime lenders:

Table Seven (B)

CONVENTIONAL HOME MORTGAGE LENDING

APPLICATIONS RECEIVED AND PERCENTAGE CHANGE

SUBPRIME LENDERS

NEW YORK METROPOLITAN AREA

1998-1999

\begin{tabular}{|l|c|c|c|}
\hline & 1998 & 1999 & \% CHANGE \\
\hline \multicolumn{4}{|c|}{ APPLICANT CHARACTERISTICS } \\
\hline Minority & 4,609 & 3,400 & -26.2 \\
\hline White & 3,831 & 2,304 & -39.9 \\
\hline LMI & 2,263 & 2,458 & 8.6 \\
\hline UI & 8,338 & 6,852 & -17.8 \\
\hline \multicolumn{4}{|c|}{ NEIGHBORHOOD CHARACTERISTICS } \\
\hline 80-100\% Min. & 4,894 & 4,181 & -14.6 \\
\hline $0-19 \%$ Min. & 9,314 & 6,156 & -33.9 \\
\hline LMI & 3,434 & 2,956 & -13.9 \\
\hline UI & 10,774 & 7,381 & -31.5 \\
\hline
\end{tabular}

According to Table Seven (B), applications for conventional home mortgage loans to subprime lenders declined in all communities except LMI individuals. The declines were fairly significant, and the rate of decline was greater in the control communities. 
Finally, Table Seven (C) shows the percentage of all conventional home mortgage loan applications each community submitted to subprime lenders in 1998 and 1999 and the percentage change:

Table Seven (C)

CONVENTIONAL HOME MORTGAGE LENDING

PERCENTAGE OF APPLICATIONS SUBMITTED TO SUBPRIME LENDERS AND PERCENTAGE CHANGE

NEW YORK METROPOLITAN AREA

1998-1999

\begin{tabular}{|l|c|c|c|}
\hline \multicolumn{3}{|c|}{ APPLICANT CHARACTERISTICS } \\
\hline Minority & 19.3 & 12.3 & -36.2 \\
\hline White & 8.2 & 4.5 & -45.1 \\
\hline LMI & 22.4 & 17.9 & -20.1 \\
\hline UI & 15.8 & 9.2 & -41.8 \\
\hline & NEIGHBORHOOD CHARACTERISTICS \\
\hline 80-100\% Min. & 38.6 & 30.5 & -21.0 \\
\hline 0-19\% Min. & 19.6 & 7.5 & -61.8 \\
\hline LMI & 36.2 & 26.9 & -25.7 \\
\hline UI & 19.0 & 8.7 & -54.2 \\
\hline
\end{tabular}


According to Table Seven (C), all communities under study submitted relatively fewer conventional home mortgage loan applications to subprime lenders in 1999 . The decline was significantly greater in the control communities than the subject communities.

\section{b. Originations}

Table Eight shows the number of conventional home mortgage loans originated in each subject community in 1998 and 1999, the percentage increase, and the score:

Table Eight

CONVENTIONAL HOME MORTGAGE LENDING

LOANS ORIGINATED AND PERCENTAGE CHANGE

NEW YORK METROPOLITAN AREA

1998-1999

\begin{tabular}{|c|c|c|c|c|}
\hline 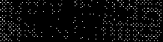 & 1998 & 1999 & $\%$ CHANGE & $+/-$ \\
\hline \multicolumn{5}{|c|}{ APPLICANT CHARACTERISTICS } \\
\hline Minority & 15,344 & 17,332 & 12.9 & +1 \\
\hline White & 35,134 & 37,179 & 5.8 & \\
\hline LMI & 5,377 & 7,976 & 48.3 & +1 \\
\hline UI & 37,211 & 50,535 & 35.8 & \\
\hline \multicolumn{5}{|c|}{ NEIGHBORHOOD CHARACTERISTICS } \\
\hline $\begin{array}{l}80-100 \% \\
\text { Min. }\end{array}$ & 6,330 & 6,499 & 2.7 & -1 \\
\hline $0-19 \%$ Min. & 34,543 & 56,495 & 63.5 & \\
\hline LMI & 4,960 & 5,569 & 12.3 & -1 \\
\hline UI & 40,796 & 57,425 & 40.8 & \\
\hline
\end{tabular}

Table Eight shows that the total number of conventional home loan originations increased in all communities. Percentage increases ranged from 2.7 percent in predominantly minority neighborhoods to 63.5 percent in White neighborhoods. Growth in loan originations to Whites and LMI persons outgrew growth in their corresponding control 
communities, while growth in minority and LMI neighborhoods was slower than in their corresponding control communities.

Table Eight (A) examines the same criteria as Table Eight but includes prime lenders only:

Table Eight (A)

CONVENTIONAL HOME MORTGAGE LENDING

LOANS ORIGINATED AND PERCENTAGE CHANGE

PRIME LENDERS ONLY

NEW YORK METROPOLITAN AREA

1998-1999

\begin{tabular}{|c|c|c|c|}
\hline 12 & 1998 & 1999 & $\%$ CHANGE \\
\hline \multicolumn{4}{|c|}{ APPLICANT CHARACTERISTICS } \\
\hline Minority & 13,363 & 16,450 & 23.1 \\
\hline White & 33,160 & 36,484 & 10.0 \\
\hline LMI & 4,834 & 7,533 & 55.8 \\
\hline UI & 34,681 & 48,757 & 40.6 \\
\hline \multicolumn{4}{|c|}{ NEIGHBORHOOD CHARACTERISTICS } \\
\hline $80-100 \%$ Min. & 4,614 & 5,612 & 21.6 \\
\hline $0-19 \%$ Min. & 30,835 & 55,032 & 78.5 \\
\hline LMI & 3,758 & 4,939 & 31.4 \\
\hline UI & 36,574 & 55,705 & 52.3 \\
\hline
\end{tabular}

Comparing Table Eight (A) with Table Eight shows that the relative growth trends in conventional home mortgage loan originations between the subject and control communities remain constant when excluding subprime lenders; thus the results on the origination portion of the conventional home mortgage lending Scorecard do not change when examining prime lenders only. Comparing Table Eight (A) with Table Eight also shows that the growth rate in conventional home mortgage loan originations was greater in all communities when excluding subprime lenders. Additionally, with the exception of minority and White individuals, the growth rate in control communities was greater in the subject communities. 
Table Eight (B), in contrast, examines the same criteria as Table Eight, but includes subprime lenders only:

Table Eight (B)

CONVENTIONAL HOME MORTGAGE LENDING

LOANS ORIGINATED AND PERCENTAGE CHANGE

NEW YORK METROPOLITAN AREA

SUBPRIME LENDERS ONLY

1998-1999

\begin{tabular}{|l|c|c|c|}
\hline & 1998 & 1999 & \% CHANGE \\
\hline \multicolumn{4}{|c|}{ APPLICANT CHARACTERISTICS } \\
\hline Minority & 1,981 & 882 & -55.4 \\
\hline White & 1,974 & 695 & -64.8 \\
\hline LMI & 543 & 443 & -18.4 \\
\hline UI & 2,530 & 1,778 & -29.7 \\
\hline & NEIGHBORHOOD CHARACTERISTICS \\
\hline 80-100\% Min. & 1,716 & 887 & -48.3 \\
\hline 0-19\% Min. & 3,708 & 1,463 & -60.5 \\
\hline LMI & 1,202 & 630 & -47.6 \\
\hline UI & 4,222 & 1,720 & -59.3 \\
\hline
\end{tabular}

Table Eight (B) shows that subprime lenders originated far fewer conventional home mortgage loans in all communities under study in 1999. The decline, however, was greater in the control communities under study than in the subject communities. 
Finally, Table Eight (C) shows the percentage of all conventional home mortgage loan originations subprime lenders made in each community in 1998 and 1999 and the percentage change:

Table Eight (C)

CONVENTIONAL HOME MORTGAGE LENDING

PERCENTAGE OF LOANS ORIGINATED BY SUBRIME LENDERS AND

PERCENTAGE CHANGE

NEW YORK METROPOLITAN AREA

1998-1999

\begin{tabular}{|c|c|c|c|}
\hline (1) & 1998 & 1999 & $\%$ CHANGE \\
\hline \multicolumn{4}{|c|}{ APPLICANT CHARACTERISTICS } \\
\hline Minority & 12.9 & 5.1 & -60.5 \\
\hline White & 5.6 & 1.9 & -66.1 \\
\hline LMI & 10.1 & 5.6 & -44.6 \\
\hline UI & 6.8 & 3.5 & -48.5 \\
\hline \multicolumn{4}{|c|}{ NEIGHBORHOOD CHARACTERISTICS } \\
\hline $80-100 \%$ Min. & 27.1 & 13.6 & -49.8 \\
\hline $0-19 \%$ Min. & 10.7 & 2.6 & -76.0 \\
\hline LMI & 24.2 & 11.3 & -53.3 \\
\hline UI & 10.3 & 3.0 & -70.1 \\
\hline
\end{tabular}

Table Eight (C) shows that subprime conventional home mortgage loans as a percentage of all conventional home mortgage lending dropped in all communities in 1999. With the exception of minority individuals, the declines were greater in the control communities than in the subject communities. In addition, Table Eight (C) shows that subprime conventional home mortgage lending remained a much greater part of conventional home mortgage lending in the subject communities than in the control communities. 


\author{
c. Denial rate ratios
}

Table Nine depicts the denial rates and denial rate ratios for each subject community in 1998 and 1999 as well as the score:

Table Nine

CONVENTIONAL HOME MORTGAGE LENDING

DENIAL RATE RATIOS

NEW YORK METROPOLITAN AREA 1998-1999

\begin{tabular}{|c|c|c|c|c|c|}
\hline 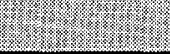 & \multicolumn{2}{|c|}{1998} & \multicolumn{2}{|c|}{1999} & $+/-$ \\
\hline (2) & $\begin{array}{c}\text { DENIAL } \\
\text { RATE }\end{array}$ & $\begin{array}{c}\text { DENIAL } \\
\text { RATE } \\
\text { RATIO } \\
\end{array}$ & $\begin{array}{c}\text { DENIAL } \\
\text { RATE }\end{array}$ & $\begin{array}{c}\text { DENIAL } \\
\text { RATE } \\
\text { RATIO } \\
\end{array}$ & \\
\hline \multicolumn{6}{|c|}{ APPLICANT CHARACTERISTICS } \\
\hline Minority & 17.6 & 1.7 & 16.5 & 1.4 & +1 \\
\hline LMI & 22.7 & 2.0 & 20.4 & 1.7 & +1 \\
\hline \multicolumn{6}{|c|}{ NEIGHBORHOOD CHARACTERISTICS } \\
\hline $\begin{array}{l}80-100 \% \\
\text { Min. }\end{array}$ & 21.0 & 2.0 & 26.2 & 1.9 & +1 \\
\hline LMI & 20.5 & 1.8 & 24.9 & 1.7 & +1 \\
\hline
\end{tabular}

According to Table Nine, the conventional home mortgage loan denial rate ratio decreased for all subject communities, but the ratios remain relatively high. The ratio for predominantly minority neighborhoods (1.9) is consistent with discrimination against such neighborhoods. ${ }^{33}$ However, the HMDA data that is the source of this result is not sufficiently detailed to permit a definitive conclusion about discrimination. ${ }^{34}$ Nevertheless, the evidence of discrimination is sufficiently strong to merit further investigation by government agencies that have the authority to obtain the necessary information. ${ }^{35}$ Although not depicted in Table Nine, the denial rate ratios for subprime lenders was 1.1 for minority individuals, 1.4 for LMI individuals, and 1.2 for

\footnotetext{
${ }^{33}$ See Marsico, supra note 6, at 516-18.

${ }^{34}$ See id. at 516-17.

${ }^{35}$ See id. at 529.
} 
predominantly minority and LMI neighborhoods. Although subprime lender denial rate ratios were low, subprime lender denial rates were higher than for all lenders combined, ranging from 31 percent for minority individuals, 36 percent for minority neighborhoods, 38 percent for LMI neighborhoods, and 41 percent for LMI persons.

\section{d. Minority Individuals}

Focusing next on one of the subject communities - minority individuals - HMDA makes it possible to divide minority individuals into four sub-groups: Native Americans; Asians/Pacific Islanders; African-Americans; and Latinos. It is possible to compare conventional home mortgage lending to each of these groups to conventional home mortgage lending to Whites, and thus to apply each of the three indicators for evaluating conventional home mortgage lending to each of these four groups. The results of this analysis are depicted in Table Ten:

Table Ten

CONVENTIONAL HOME MORTGAGE LENDING

RACE OF APPLICANTS

NEW YORK METROPOLITAN AREA

1998-1999

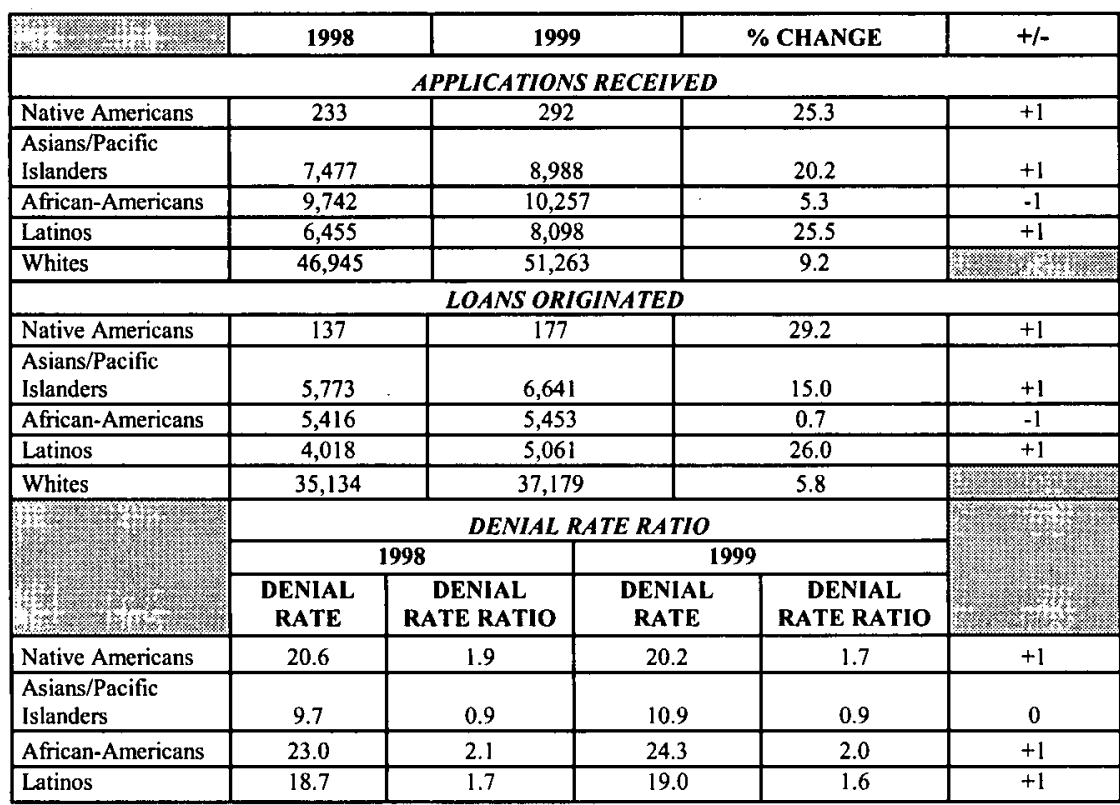


Table Ten shows that conventional home mortgage loan applications and originations increased for all five groups in 1999. Of the four minority groups depicted in Table Ten, Native Americans and Latinos fared the best with scores of +3 . Application and loan growth in these communities were greater than for Whites, and their denial rate ratios decreased. Asians/Pacific Islanders scored +2 ; application and loan origination growth was greater than for Whites but the denial rate ratio remained the same. African-Americans received -1 , as application and loan growth was slower than for Whites but the denial rate ratio decreased. Denial rate ratios for African-Americans (2.0) and Native Americans (1.7), were consistent with discrimination, although not fully probative of discrimination. ${ }^{36}$

Among the groups depicted in Table Ten, there were wide disparities in the percentages of applications they submitted to and loans they received from subprime lenders. These are depicted in Table Ten (A):

Table Ten (A)

PERCENTAGE OF APPLICATIONS SUBMITTED TO AND LOANS ORIGINATED

BY CONVENTIONAL HOME MORTGAGE LOAN SUBPRIME LENDERS BY RACIAL GROUP

NEW YORK METROPOLITAN AREA 1999

\begin{tabular}{|l|c|c|}
\hline \multicolumn{1}{|c|}{ RACE } & APPLICATIONS & ORIGINATIONS \\
\hline Native American & 25.7 & 19.2 \\
\hline Asian/Pacific Islander & 3.5 & 13.6 \\
\hline African-American & 20.9 & 9.5 \\
\hline Latino & 10.7 & 4.7 \\
\hline White & 4.5 & 1.9 \\
\hline
\end{tabular}

e. Conclusion

In conclusion, conventional home mortgage lending grew for all communities in the metropolitan area in 1999, and growth in the subject communities slightly outpaced growth in the control communities, these denial rate ratios.

${ }^{36}$ See supra text accompanying notes $33-35$ for a discussion of the meaning of 
resulting in an overall score of +2 . Among the subject communities, minority individuals fared the best with +3 , LMI individuals scored +1 , and minority and LMI neighborhoods each scored -1 . Among minority individuals, Native Americans and Latinos received +3 , while AfricanAmericans lagged behind Whites in application and lending growth. In addition, conventional home mortgage loan denial rate ratios were consistent with discrimination for predominantly minority neighborhoods, African-Americans, and Native Americans. Subprime conventional home mortgage lending declined in all communities in 1999. The declines were generally greater in the control communities than in the subject communities. Subprime lending constituted a larger portion of all conventional home mortgage lending in the control communities, particularly in predominantly minority and LMI neighborhoods.

\section{CONVENTIONAL Home MoRTGage Lending By Individual LENDERS IN THE NEW YORK METROPOLITAN AREA}

\section{A. Methodology}

Part Two evaluates the conventional home mortgage lending record of the 152 lenders in the New York metropolitan area that made at least 30 conventional home mortgage loans in $1999 .{ }^{37}$ This section examines each lender's conventional home mortgage lending record to the four subject communities: minority persons; LMI persons; predominantly minority neighborhoods; and LMI neighborhoods.

This section evaluates each lender's conventional home mortgage lending record to these four communities by using five indicators. These indicators are designed to do two things. The first three indicators compare each lender's record in each subject community to the record for all lenders combined in the New York metropolitan area in each subject community. The fourth and fifth indicators compare each lender's record

${ }^{37}$ Together, these lenders made 61,354 conventional home mortgage loans, or 97 percent of all conventional home mortgage loans in the New York metropolitan area in 1999. 
in each subject community to its own record in each control community.

The five indicators are:

*Percentage of conventional home mortgage loan applications received: This indicator compares the percentage of conventional home mortgage loan applications the lender received from each subject community to the percentage of conventional home mortgage applications each subject community submitted to all lenders combined in the metropolitan area.

*Percentage of conventional home mortgage loans originated: This indicator compares the percentage of the lender's conventional home mortgage loans originated to each subject community to the percentage of conventional home mortgage loans all lenders combined originated to each subject community in the metropolitan area.

*Conventional home mortgage loan application denial rate ratio: This indicator compares the lender's denial rate ratio on conventional home mortgage loan applications for each subject community to the denial rate ratio for each subject community for all lenders combined in metropolitan area.

* Market share of conventional home mortgage loan applications: This indicator compares the lender's market share of conventional home mortgage loan applications in each subject community to the lender's market share of conventional home mortgage loan applications in each subject community's control community.

* Market share of conventional home mortgage loan originations: This indicator measures each lender's market share of conventional home mortgage loan 
originations in each subject community to its market share of conventional home mortgage loan originations in each subject community's control community.

Applying each of the five indicators to each of the four subject communities yields twenty indicators for evaluating conventional home mortgage lending for each lender:

1. Percentage of applications from minority persons: the percentage of the lender's applications from minority persons compared to the percentage of all applications in the metropolitan area from minority persons.

2. Percentage of applications from LMI persons: the percentage of the lender's applications from LMI persons compared to the percentage of all applications in the metropolitan area from LMI persons.

\section{Percentage of applications for loans to purchase property in predominantly minority neighborhoods: the percentage of the lender's applications for loans to purchase property in predominantly minority neighborhoods compared to the percentage of all applications in the metropolitan area for loans to purchase property in predominantly minority neighborhoods.}

4. Percentage of applications for loans to purchase property in LMI neighborhoods: the percentage of all the lender's applications for loans to purchase property in LMI neighborhoods compared to the percentage of all applications in the metropolitan area for loans to purchase property in LMI neighborhoods.

5. Percentage of loan originations to minority persons: the percentage of the lender's loan originations to minority persons compared to the percentage of all 
loan originations in the metropolitan area to minority persons.

6. Percentage of loan originations to LMI persons: the percentage of the lender's loan originations to LMI persons compared to the percentage of all loan originations in the metropolitan area to LMI persons.

7. Percentage of loan originations to purchase property in predominantly minority neighborhoods: the percentage of the lender's loan originations to purchase property in predominantly minority neighborhoods compared to the percentage of all originations in the metropolitan area to purchase property in predominantly minority neighborhoods.

8. Percentage of loan originations to purchase property in LMI neighborhoods: the percentage of the lender's loan originations to purchase property in LMI neighborhoods compared to the percentage of all originations in the metropolitan area to purchase property in LMI neighborhoods.

9. Denial rate ratio -- minority/White applicants: the lender's denial rate ratio for minority/White loan applicants compared to the metropolitan area minority/White applicant denial rate ratio.

10. Denial rate ratio - LMI/UI applicants: the lender's denial rate ratio for LMI/UI loan applicants compared to the metropolitan area LMI/UI applicant denial rate ratio.

11. Denial rate ratio - predominantly minority/predominantly White neighborhoods: the lender's denial rate ratio for predominantly 
minority/predominantly White neighborhoods compared to the metropolitan area predominantly minority/predominantly White neighborhood denial rate ratio.

12. Denial rate ratio - LMI/UI neighborhoods: the lender's denial rate ratio for LMI/UI neighborhoods compared to the metropolitan area LMI/UI neighborhood denial rate ratio.

13. Market share of applications - minority persons: the lender's market share of applications from minority persons compared to its market share of applications from White persons.

14. Market share of applications - LMI persons: the lender's market share of applications from LMI persons compared to its market share of applications from UI persons.

15. Market share of applications - property in predominantly minority neighborhoods: the lender's market share of applications for loans to purchase property in predominantly minority neighborhoods compared to its market share of applications for loans to purchase property in predominantly White neighborhoods.

16. Market share of applications - property in LMI neighborhoods: the lender's market share of applications for loans to purchase property in LMI neighborhoods compared to its market share of applications for loans to purchase property in UI neighborhoods. 


\begin{abstract}
17. Market share of loan originations - minority persons: the lender's market share of loan originations to minority persons compared to its market share of loan originations to White persons.
\end{abstract}

18. Market share of loan originations - LMI persons: the lender's market share of loan originations to LMI persons compared to its market share of loan originations to UI persons.

19. Market share of loan originations - property in predominantly minority neighborhoods: the lender's market share of loan originations in predominantly minority neighborhoods compared to its market share of loan originations in White neighborhoods.

\title{
20. Market share of loan originations - property in
}

LMI neighborhoods: The lender's market share of loan originations in LMI neighborhoods compared to its market share of loan originations in UI neighborhoods.

This section assigns a score to each lender's record for each of these twenty indicators as follows. If a lender's percentage of applications from or loans to a subject community is higher than the metropolitan area percentage for all lenders, it receives +1 ; if its percentage is lower, the lender receives -1 . If the lender's market share of applications from or loans to a subject community is higher than its market share in the corresponding control community, the lender receives +1 . The lender receives -1 for a smaller market share in a subject community. If the lender's denial rate ratio for a subject community is higher than the metropolitan area denial rate ratio, it receives -1 ; it receives +1 if its denial rate ratio is lower. The same percentage, market share, or denial rate ratio earns a 0 . For example, if 15 percent of a lender's conventional home mortgage loans are to LMI persons and 12 percent of all loans by all lenders in the metropolitan area are to LMI persons, the lender will receive +1 . If the lender's market share of applications in predominantly minority neighborhoods is one percent and 
its market share of applications in predominantly White neighborhoods is .5 percent, the lender will receive +1 as well. If its denial rate ratio for minority persons is lower than the metropolitan area denial rate ratio, it will also receive +1 . The Scorecard tabulates each lender's score for all indicators, assigns a point total, and ranks each lender accordingly.

\section{B. Results}

\section{Individual Lenders}

Table Eleven is the "Scorecard" for individual lenders. ${ }^{38}$

Table Eleven

SCORECARD

CONVENTIONAL HOME MORTGAGE LENDING

INDIVIDUAL LENDERS - THIRTY OR MORE LOANS

NEW YORK METROPOLITAN AREA

1999

\begin{tabular}{|c|l|c|c|c|}
\hline RANKING & \multicolumn{1}{|c|}{ LENDER } & LOANS & $\begin{array}{c}\text { PERCENT } \\
\text { OF ALL } \\
\text { LOANS }\end{array}$ & SCORE \\
\hline 1 & CFS BANK & 620 & $0.98 \%$ & 20 \\
\hline 1 & $\begin{array}{l}\text { FREMONT INVESTMENT \& } \\
\text { LOAN* }\end{array}$ & 151 & $0.24 \%$ & 20 \\
\hline 1 & $\begin{array}{l}\text { ASSOCIATES FINANCIAL } \\
\text { SERVICES* }\end{array}$ & 103 & $0.16 \%$ & 20 \\
\hline 1 & $\begin{array}{l}\text { PREMIER MORTGAGE } \\
\text { BANKING CORP. }\end{array}$ & 88 & $0.14 \%$ & 20 \\
\hline 1 & SUPERIOR BANK* & 323 & $0.51 \%$ & 20 \\
\hline 1 & $\begin{array}{l}\text { GOLDEN NATIONAL } \\
\text { MORTGAGE }\end{array}$ & 399 & $0.63 \%$ & 20 \\
\hline 1 & $\begin{array}{l}\text { 1st REPUBLIC MORTGAGE } \\
\text { BANKERS }\end{array}$ & 275 & $0.44 \%$ & 20 \\
\hline 1 & $\begin{array}{l}\text { ABACUS FEDERAL } \\
\text { SAVINGS BANK }\end{array}$ & 335 & $0.53 \%$ & 20 \\
\hline
\end{tabular}

${ }^{38}$ The results on all twenty indicators and the total score for each of the 152 lenders represented in the Scorecard are available from the author. The Scorecard identifies subprime lenders with an "*” following the lender's name. It identifies lenders that specialize in making loans to purchase manufactured homes - homes constructed in a factory and assembled on-site - with an "M" following the lender's name. 


\begin{tabular}{|c|c|c|c|c|}
\hline 9 & $\begin{array}{l}\text { LONG BEACH MORTGAGE } \\
\text { COMPANY* }\end{array}$ & 76 & $0.12 \%$ & 18 \\
\hline 9 & $\begin{array}{l}\text { BANCO POPULAR NORTH } \\
\text { AMERICA }\end{array}$ & 293 & $0.47 \%$ & 18 \\
\hline 9 & $\begin{array}{l}\text { CONSECO FINANCE } \\
\text { SERVICING GROUP(M) }\end{array}$ & $\overline{45}$ & $0.07 \%$ & 18 \\
\hline 9 & $\begin{array}{l}\text { VANDERBILT } \\
\text { MORTGAGE(M) }\end{array}$ & 83 & $0.13 \%$ & 18 \\
\hline 9 & EHOMECREDIT CORP* & 36 & $0.06 \%$ & 18 \\
\hline 9 & REPUBLIC NATIONAL BANK & 125 & $0.20 \%$ & 18 \\
\hline 9 & WMC MORTGAGE CORP.* & 49 & $0.08 \%$ & 18 \\
\hline 9 & PMCC MORTGAGE CORP.* & 278 & $0.44 \%$ & 18 \\
\hline 9 & $\begin{array}{l}\text { PROFESSIONAL MORTGAGE } \\
\text { BANKER'S }\end{array}$ & 34 & $0.05 \%$ & 18 \\
\hline 18 & $\begin{array}{l}\text { ACCREDITED HOME } \\
\text { LENDERS* }\end{array}$ & 49 & $0.08 \%$ & 16 \\
\hline 18 & $\begin{array}{l}\text { CROSSLAND MORTGAGE } \\
\text { CORP. }\end{array}$ & 356 & $0.57 \%$ & 16 \\
\hline 18 & $\begin{array}{l}\text { SOUTHERN STAR } \\
\text { MORTGAGE CORP. }\end{array}$ & 107 & $0.17 \%$ & 16 \\
\hline 18 & $\begin{array}{l}\text { AMERICAN CAPITAL } \\
\text { MORTGAGE BANK }\end{array}$ & 114 & $0.18 \%$ & 16 \\
\hline 18 & FLEET NATIONAL BANK & 105 & $0.17 \%$ & 16 \\
\hline 18 & $\begin{array}{l}\text { AMERITRUST NATIONAL } \\
\text { MORTGAGE }\end{array}$ & 114 & $0.18 \%$ & 16 \\
\hline 24 & $\begin{array}{l}\text { INDYMAC MORTAGE } \\
\text { HOLDINGS INC. }\end{array}$ & 1,421 & $2.26 \%$ & 14 \\
\hline 24 & $\begin{array}{l}\text { ASSOCIATES HOME EQUITY } \\
\text { SERVICE* }^{*}\end{array}$ & 33 & $0.05 \%$ & 14 \\
\hline 24 & $\begin{array}{l}\text { ALLIANCE MORTGAGE } \\
\text { BANKING CORP. }\end{array}$ & 142 & $0.23 \%$ & 14 \\
\hline 27 & SOURCE ONE MORTGAGE & 55 & $0.09 \%$ & 12 \\
\hline 27 & $\begin{array}{l}\text { SMITH-HAVEN MORTGAGE } \\
\text { CORP. }\end{array}$ & 78 & $0.12 \%$ & 12 \\
\hline 27 & $\begin{array}{l}\text { CHINATOWN FEDERAL } \\
\text { SAVNGS BANK }\end{array}$ & 78 & $0.12 \%$ & 12 \\
\hline 27 & $\begin{array}{l}\text { PONCE DE LEON FEDERAL } \\
\text { BANK }\end{array}$ & 43 & $0.07 \%$ & 12 \\
\hline 27 & $\begin{array}{l}\text { RESIDENTIAL FUNDING } \\
\text { CORP. }\end{array}$ & 163 & $0.26 \%$ & 12 \\
\hline 27 & $\begin{array}{l}\text { FIRST ESTATE FUNDING } \\
\text { CORP. }\end{array}$ & 99 & $0.16 \%$ & 12 \\
\hline 27 & DELTA FUNDING CORP.* & 139 & $0.22 \%$ & 12 \\
\hline
\end{tabular}




\begin{tabular}{|c|c|c|c|c|}
\hline 27 & CENTEX CREDIT CORP.* & 68 & $0.11 \%$ & 12 \\
\hline 27 & $\begin{array}{l}\text { GREENPOINT MORTGAGE } \\
\text { FUNDING }\end{array}$ & 1,682 & $2.67 \%$ & 12 \\
\hline 27 & $\begin{array}{l}\text { ALL MONEY MORTGAGE } \\
\text { BANKERS }\end{array}$ & 38 & $0.06 \%$ & 12 \\
\hline 27 & MORTGAGE DEPOT CORP. & 73 & $0.12 \%$ & 12 \\
\hline 27 & $\begin{array}{l}\text { MID-ISLAND EQUITIES } \\
\text { CORP. }\end{array}$ & 239 & $0.38 \%$ & 12 \\
\hline 39 & FLEET MORTGAGE CORP. & 670 & $1.06 \%$ & 10 \\
\hline 39 & $\begin{array}{l}\text { ROSLYN NATIONAL } \\
\text { MORTGAGE CORP. }\end{array}$ & 462 & $0.73 \%$ & 10 \\
\hline 39 & MUNICIPAL CREDIT UNION & 86 & $0.14 \%$ & 10 \\
\hline 39 & WALL STREET MORTAGE & 374 & $0.59 \%$ & 10 \\
\hline 39 & $\begin{array}{l}\text { NATIONAL CITY } \\
\text { MORTGAGE }\end{array}$ & 337 & $0.53 \%$ & 10 \\
\hline 39 & $\begin{array}{l}\text { ISLAND MORTGAGE } \\
\text { NETWORK, INC. }\end{array}$ & 61 & $0.10 \%$ & 10 \\
\hline 39 & MADISON HOME EQUITIES & 362 & $0.57 \%$ & 10 \\
\hline 39 & $\begin{array}{l}\text { FIRST RESIDENTIAL } \\
\text { MORTGAGE }\end{array}$ & 34 & $0.05 \%$ & 10 \\
\hline 39 & AAMES FUNDING CORP.* & 30 & $0.05 \%$ & 10 \\
\hline 39 & $\begin{array}{l}\text { CONTINENTAL CAPITAL } \\
\text { CORP. }\end{array}$ & 125 & $0.20 \%$ & 10 \\
\hline 39 & $\begin{array}{l}\text { CONSUMER HOME } \\
\text { MORTGAGE, INC. }\end{array}$ & 77 & $0.12 \%$ & 10 \\
\hline 39 & $\begin{array}{l}\text { OPTION ONE MORTGAGE } \\
\text { CORP.* }\end{array}$ & 85 & $0.13 \%$ & 10 \\
\hline 39 & $\begin{array}{l}\text { SAXON NATIONAL } \\
\text { MORTGAGE BANKER }\end{array}$ & 53 & $0.08 \%$ & 10 \\
\hline 52 & $\begin{array}{l}\text { MORTGAGE LENDING OF } \\
\text { AMERICA }\end{array}$ & 130 & $0.21 \%$ & 8 \\
\hline 52 & $\begin{array}{l}\text { CHASE MANHATTAN } \\
\text { MORTGAGE CORP. }\end{array}$ & 1,383 & $2.20 \%$ & 8 \\
\hline 52 & $\begin{array}{l}\text { THE MORTGAGE MONEY } \\
\text { CENTER }\end{array}$ & 94 & $0.15 \%$ & 8 \\
\hline 52 & CHASE MANHATTAN BANK & 7,512 & $11.92 \%$ & 8 \\
\hline 52 & $\begin{array}{l}\text { MUTUAL OF NORTH } \\
\text { AMERICA }\end{array}$ & 30 & $0.05 \%$ & 8 \\
\hline 52 & $\begin{array}{l}\text { NATIONSCREDIT } \\
\text { FINANCIAL SERVICE* }\end{array}$ & 312 & $0.50 \%$ & 8 \\
\hline 58 & $\begin{array}{l}\text { TEMPLE-INLAND } \\
\text { MORTGAGE CO. }\end{array}$ & 52 & $0.08 \%$ & 6 \\
\hline
\end{tabular}




\begin{tabular}{|c|c|c|c|c|}
\hline 58 & CHARTER ONE BANK & 65 & $0.10 \%$ & 6 \\
\hline 58 & $\begin{array}{l}\text { MORTGAGE LENDERS } \\
\text { NETWORK USA* }\end{array}$ & 34 & $0.05 \%$ & 6 \\
\hline 61 & HSBC MORTGAGE CORP. & 2,070 & $3.29 \%$ & 4 \\
\hline 61 & $\begin{array}{l}\text { ACTORS FEDERAL CREDIT } \\
\text { UNION }\end{array}$ & 33 & $0.05 \%$ & 4 \\
\hline 61 & $\begin{array}{l}\text { MORTGAGE PLUS EQUITY } \\
\text { \& LOAN* }\end{array}$ & 36 & $0.06 \%$ & 4 \\
\hline 64 & $\begin{array}{l}\text { MASPETH FEDERAL } \\
\text { SAVINGS AND LOAN }\end{array}$ & 311 & $0.49 \%$ & 2 \\
\hline 64 & FLUSHING SAVINGS BANK & 166 & $0.26 \%$ & 2 \\
\hline 64 & $1^{\mathrm{ST}} 2^{\mathrm{ND}}$ MORTGAGE CO. NJ & 61 & $0.10 \%$ & 2 \\
\hline 64 & $\begin{array}{l}\text { HOMECOMINGS FINANCIAL } \\
\text { NETWORK }\end{array}$ & 94 & $0.15 \%$ & 2 \\
\hline 64 & $\begin{array}{l}\text { REPUBLIC CONSUMER } \\
\text { LENDING GROUP }\end{array}$ & 3,144 & $4.99 \%$ & 2 \\
\hline 69 & FLEET BANK & 50 & $0.08 \%$ & 0 \\
\hline 69 & UFSB OF INDIANAPOLIS & 184 & $0.29 \%$ & 0 \\
\hline 69 & $\begin{array}{l}\text { COUNTRYWIDE HOME } \\
\text { LOANS }\end{array}$ & 1,182 & $1.88 \%$ & 0 \\
\hline 69 & $\begin{array}{l}\text { SUMA (YONKERS) FEDERAL } \\
\text { CREDIT UNION }\end{array}$ & 30 & $0.05 \%$ & $\overline{0}$ \\
\hline 69 & $\begin{array}{l}\text { BNY MORTGAGE } \\
\text { COMPANY LLC }\end{array}$ & 1,125 & $1.79 \%$ & $\overline{0}$ \\
\hline$\overline{74}$ & $\begin{array}{l}\text { NORTH AMERICAN } \\
\text { MORTGAGE CO. }\end{array}$ & 114 & $0.18 \%$ & -2 \\
\hline$\overline{74}$ & $\begin{array}{l}\text { OLYMPIA MORTGAGE } \\
\text { CORP. }\end{array}$ & 74 & $0.12 \%$ & -2 \\
\hline$\overline{76}$ & $\begin{array}{l}\text { NORTHFIELD SAVINGS } \\
\text { BANK }\end{array}$ & $\overline{174}$ & $0.28 \%$ & -4 \\
\hline$\overline{76}$ & EAB MORTGAGE COMPANY & 1,076 & $1.71 \%$ & -4 \\
\hline 76 & FT MORTGAGE COMPANIES & 52 & $0.08 \%$ & -4 \\
\hline 76 & $\overline{\mathrm{UNFCU}}$ & $\overline{197}$ & $0.31 \%$ & -4 \\
\hline 76 & $\begin{array}{l}\text { BRUCHA MORTGAGE } \\
\text { BANKERS }\end{array}$ & $\overline{203}$ & $0.32 \%$ & -4 \\
\hline 76 & $\begin{array}{l}\text { SLEEPY HOLLOW } \\
\text { NATIONAL BANK }\end{array}$ & 45 & $0.07 \%$ & -4 \\
\hline 76 & $\begin{array}{l}\text { SELF RELIANCE (NY) } \\
\text { FEDERAL CREDIT UNION }\end{array}$ & 39 & $0.06 \%$ & -4 \\
\hline 76 & $\begin{array}{l}\text { POLISH \& SLAVIC FEDERAL } \\
\text { CREDIT UNION }\end{array}$ & 70 & $0.11 \%$ & -4 \\
\hline 76 & $\begin{array}{l}\text { CHASE MORTGAGE } \\
\text { COMPANY-WEST }\end{array}$ & 153 & $0.24 \%$ & -4 \\
\hline
\end{tabular}




\begin{tabular}{|c|c|c|c|c|}
\hline 85 & $\begin{array}{l}\text { GE CAPITAL MORTGAGE } \\
\text { SERVICES }\end{array}$ & 276 & $0.44 \%$ & -6 \\
\hline 85 & $\begin{array}{l}\text { WASHINGTON MUTUAL } \\
\text { BANK }\end{array}$ & 2,011 & $3.19 \%$ & -6 \\
\hline 85 & $\begin{array}{l}\text { NATIONAL STANDARD } \\
\text { MORTGAGE CORP. }\end{array}$ & 34 & $0.05 \%$ & -6 \\
\hline 85 & $\begin{array}{l}\text { MORTGAGE LINE FINANCIAL } \\
\text { CORP. }\end{array}$ & 111 & $0.18 \%$ & -6 \\
\hline 89 & M\&T MORTGAGE CORP. & 917 & $1.46 \%$ & -8 \\
\hline 89 & $\begin{array}{l}\text { EMIGRANT MORTGAGE } \\
\text { COMPANY }\end{array}$ & 590 & $0.94 \%$ & -8 \\
\hline 89 & $\begin{array}{l}\text { REPUBLICAN BANCORP } \\
\text { MORTGAGE INC. }\end{array}$ & 40 & $0.06 \%$ & -8 \\
\hline 89 & BANK OF AMERICA & 1,838 & $2.92 \%$ & -8 \\
\hline 89 & $\begin{array}{l}\text { DIME SAVINGS BANK OF } \\
\text { NEW YORK }\end{array}$ & 1,888 & $3.00 \%$ & -8 \\
\hline 94 & CITIBANK & 2,401 & $3.81 \%$ & -10 \\
\hline 94 & MORTGAGE.COM* & 91 & $0.14 \%$ & -10 \\
\hline 94 & $\begin{array}{l}\text { PREMIER NATIONAL } \\
\text { BANCORP }\end{array}$ & 47 & $0.07 \%$ & -10 \\
\hline 97 & $\begin{array}{l}\text { SAFRA NATIONAL BANK OF } \\
\text { NY }\end{array}$ & 107 & $0.17 \%$ & -12 \\
\hline 97 & CITICORP MORTGAGE INC. & 1,610 & $2.56 \%$ & -12 \\
\hline 97 & $\begin{array}{l}\text { KRAFT FOODS FEDERAL } \\
\text { CREDIT UNION }\end{array}$ & 34 & $0.05 \%$ & -12 \\
\hline 97 & SUMMIT BANK & 32 & $0.05 \%$ & -12 \\
\hline 97 & HUDSON VALLEY BANK & 58 & $0.09 \%$ & -12 \\
\hline 97 & BANK UNITED & 51 & $0.08 \%$ & -12 \\
\hline 97 & ULSTER SAVINGS BANK & 146 & $0.23 \%$ & -12 \\
\hline 97 & $\begin{array}{l}\text { MAHOPAC NATIONAL } \\
\text { BANK }\end{array}$ & 106 & $0.17 \%$ & -12 \\
\hline 97 & PROVIDENT BANK & 220 & $0.35 \%$ & -12 \\
\hline 97 & WEBSTER BANK & 76 & $0.12 \%$ & -12 \\
\hline 97 & SOUND FEDERAL S\&L & 75 & $0.12 \%$ & -12 \\
\hline 97 & $\begin{array}{l}\text { FIRST FEDERAL SAVINGS } \\
\text { BANK }\end{array}$ & 63 & $0.10 \%$ & -12 \\
\hline 97 & $\begin{array}{l}\text { CROSS COUNTY FEDERAL } \\
\text { SAVINGS BANK }\end{array}$ & 46 & $0.07 \%$ & -12 \\
\hline 97 & $\begin{array}{l}\text { HOMERICA MORTGAGE } \\
\text { CORP. }\end{array}$ & 74 & $0.12 \%$ & -12 \\
\hline 97 & PEOPLE'S BANK & 37 & $0.06 \%$ & -12 \\
\hline
\end{tabular}




\begin{tabular}{|c|c|c|c|c|}
\hline 97 & MELLON BANK & 62 & $0.10 \%$ & -12 \\
\hline 97 & FIRST REPUBLIC BANK & 37 & $0.06 \%$ & -12 \\
\hline 114 & $\begin{array}{l}\text { FIRST UNION MORTGAGE } \\
\text { CORP. }\end{array}$ & 465 & $0.74 \%$ & -14 \\
\hline 114 & NORWEST FUNDING & 127 & $0.20 \%$ & -14 \\
\hline 114 & COLUMBIA EQUITIES & 449 & $0.71 \%$ & -14 \\
\hline 114 & $\begin{array}{l}\text { PNC MORTGAGE CORP. OF } \\
\text { AMERICA }\end{array}$ & 247 & $0.39 \%$ & -14 \\
\hline 114 & MSDW CREDIT CORP. & 62 & $0.10 \%$ & -14 \\
\hline 114 & GMAC MORTGAGE & 275 & $0.44 \%$ & -14 \\
\hline 114 & $\begin{array}{l}\text { CHASE MANHATTAN BANK } \\
\text { USA }\end{array}$ & 108 & $0.17 \%$ & -14 \\
\hline 114 & MORTGAGE ACCESS CORP. & 73 & $0.12 \%$ & -14 \\
\hline 114 & APPLE BANK FOR SAVINGS & 273 & $0.43 \%$ & -14 \\
\hline 114 & $\begin{array}{l}\text { U.S. TRUST COMPANY OF } \\
\text { NEW YORK }\end{array}$ & 185 & $0.29 \%$ & -14 \\
\hline 114 & NORWEST MORTGAGE & 3,023 & $4.80 \%$ & -14 \\
\hline 114 & $\begin{array}{l}\text { PUTNAM COUNTY SAVINGS } \\
\text { BANK }\end{array}$ & 154 & $0.24 \%$ & -14 \\
\hline 126 & CHEVY CHASE BANK & 64 & $0.10 \%$ & -16 \\
\hline 126 & OHIO SAVINGS BANK & 64 & $0.10 \%$ & -16 \\
\hline 126 & $\begin{array}{l}\text { THE YONKERS SAVINGS \& } \\
\text { LOAN }\end{array}$ & 329 & $0.52 \%$ & -16 \\
\hline 126 & $\begin{array}{l}\text { FIRST UNION NATIONAL } \\
\text { BANK }\end{array}$ & 95 & $0.15 \%$ & -16 \\
\hline 126 & $\begin{array}{l}\text { STATEN ISLAND SAVINGS } \\
\text { BANK }\end{array}$ & 1,400 & $2.22 \%$ & -16 \\
\hline 126 & $\begin{array}{l}\text { LYONS MORTGAGE } \\
\text { SERVICES }\end{array}$ & 147 & $0.23 \%$ & -16 \\
\hline 126 & $\begin{array}{l}\text { STERLING NATIONAL MTG. } \\
\text { CO. INC. }\end{array}$ & 173 & $0.27 \%$ & -16 \\
\hline 126 & CTX MORTGAGE COMPANY & 71 & $0.11 \%$ & -16 \\
\hline 126 & $\begin{array}{l}\text { THE NEW YORK } \\
\text { MORTGAGE COMPANY }\end{array}$ & 110 & $0.17 \%$ & -16 \\
\hline 126 & $\begin{array}{l}\text { BOSTON SAFE DEPOSIT \& } \\
\text { TRUST CO. }\end{array}$ & 270 & $0.43 \%$ & -16 \\
\hline 126 & $\begin{array}{l}\text { THE WARWICK SAVINGS } \\
\text { BANK }\end{array}$ & 90 & $0.14 \%$ & -16 \\
\hline 126 & NORTH FORK BANK & 747 & $1.19 \%$ & -16 \\
\hline 126 & THE BANK OF NEW YORK & 88 & $0.14 \%$ & -16 \\
\hline
\end{tabular}




\begin{tabular}{|c|c|c|c|c|}
\hline 126 & E-LOAN & 33 & $0.05 \%$ & -16 \\
\hline 126 & $\begin{array}{l}\text { RICHMOND COUNTY } \\
\text { SAVINGS BANK }\end{array}$ & 722 & $1.15 \%$ & -16 \\
\hline 126 & $\begin{array}{l}\text { MERRILL LYNCH CREDIT } \\
\text { CORP. }\end{array}$ & 362 & $0.57 \%$ & -16 \\
\hline 142 & $\begin{array}{l}\text { ROYAL MORTGAGE } \\
\text { BANKERS }\end{array}$ & 50 & $0.08 \%$ & -18 \\
\hline 142 & SOVEREIGN BANK & 36 & $0.06 \%$ & -18 \\
\hline 142 & ASTORIA FEDERAL SAVINGS & 1,360 & $2.16 \%$ & -18 \\
\hline 142 & FLAGSTAR BANK & 744 & $1.18 \%$ & -18 \\
\hline 142 & $\begin{array}{l}\text { FIRST NATIONWIDE } \\
\text { MORTGAGE CORP. }\end{array}$ & 60 & $0.10 \%$ & -18 \\
\hline 142 & CENDANT MORTGAGE & 1,554 & $2.47 \%$ & -18 \\
\hline 142 & $\begin{array}{l}\text { RIDGEWOOD SAVINGS } \\
\text { BANK }\end{array}$ & 253 & $0.40 \%$ & -18 \\
\hline 149 & UNION STATE BANK & 89 & $0.14 \%$ & -20 \\
\hline 149 & $\begin{array}{l}\text { AMERICAN HOME } \\
\text { MORTGAGE CORP. }\end{array}$ & 1,536 & $2.44 \%$ & -20 \\
\hline 149 & $\begin{array}{l}\text { INDEPENDENCE } \\
\text { COMMUNITY BANK }\end{array}$ & 268 & $0.43 \%$ & -20 \\
\hline 149 & STANDARD FEDERAL BANK & 560 & $0.89 \%$ & -20 \\
\hline
\end{tabular}

As in 1998, subprime lenders as a group outperformed all other lenders in the Scorecard. All but one of the seventeen subprime lenders and both of the manufactured home lenders received scores of greater than 0 . This result is consistent with Part One, which showed that subprime lenders made a larger portion of conventional home mortgage loans in the subject communities than in the control communities.

\section{Poor Lending Records in the Subject Communities}

The following four tables identify the lenders that had poor conventional home mortgage lending records in each subject community in the New York metropolitan area in 1999, based on three criteria: a conventional home mortgage loan origination rate less than or equal to one-half the New York metropolitan area average; a market share in the subject community less than or equal to one-half of its market shares in 
the control community; and a denial rate ratio greater than or equal to the New York metropolitan area denial rate ratio. ${ }^{39}$

a. Minority individuals

Table Twelve identifies sixteen lenders who satisfy the criteria for having a poor lending record to minority individuals.

Table Twelve

MINORITY INDIVIDUALS

POOR LENDING RECORDS

CONVENTIONAL HOME MORTGAGE LENDING

NEW YORK METROPOLITAN AREA, 1999

\begin{tabular}{|c|c|c|c|}
\hline LENDER & $\begin{array}{c}\text { ORIGINATIONS } \\
(\%) \\
\text { LENDER/MSA }\end{array}$ & $\begin{array}{l}\text { MARKET SHARE } \\
(\%) \\
\text { MINORITY/WHITE }\end{array}$ & $\begin{array}{c}\text { DENIAL } \\
\text { RATE RATIO } \\
\text { LENDER/MSA }\end{array}$ \\
\hline $\begin{array}{l}\text { SAFRA NATIONAL } \\
\text { BANK OF NY }\end{array}$ & $0.0 / 30.7$ & $0.0 / .12$ & $\mathrm{~N} / \mathrm{A}$ \\
\hline $\begin{array}{l}\text { SELF RELIANCE } \\
\text { (NY) FEDERAL } \\
\text { CREDIT UNION }\end{array}$ & $0.0 / 30.7$ & $0.0 / .10$ & N/A \\
\hline $\begin{array}{l}\text { SUMA } \\
\text { (YONKERS) } \\
\text { FEDERAL CREDIT } \\
\text { UNION }\end{array}$ & $0.0 / 30.7$ & $0.0 / .08$ & N/A \\
\hline $\begin{array}{l}\text { MSDW CREDIT } \\
\text { CORP. }\end{array}$ & $3.2 / 30.7$ & $.01 / .04$ & $2.00 / 1.52$ \\
\hline $\begin{array}{l}\text { ROYAL } \\
\text { MORTGAGE } \\
\text { BANKERS }\end{array}$ & $4.0 / 30.7$ & $.01 / .12$ & $1.98 / 1.52$ \\
\hline $\begin{array}{l}\text { THE BANK OF } \\
\text { NEW YORK }\end{array}$ & $5.7 / 30.7$ & $.03 / .12$ & $10.67 / 1.52$ \\
\hline $\begin{array}{l}\text { MERRILL LYNCH } \\
\text { CREDIT CORP. }\end{array}$ & $8.3 / 30.7$ & $.16 / .48$ & $1.90 / 1.52$ \\
\hline $\begin{array}{l}\text { UNION STATE } \\
\text { BANK }\end{array}$ & $10.1 / 30.7$ & $.05 / .22$ & $5.60 / 1.52$ \\
\hline
\end{tabular}

${ }^{39}$ The lenders are arranged according to percentage of loans in the subject community, lowest percentage first. A denial rate ratio of N/A indicates that according to the available HMDA data, the lender received no applications from the subject community, and thus had no denial rate or denial rate ratio. These lenders are included on the list of poorly performing lenders in a subject community as long as they satisfy the other two criteria for placement on the list; otherwise, lenders would be left off the list only because they received no applications from the relevant subject community, which would be a misleading result. 


\begin{tabular}{|l|c|c|c|}
\hline $\begin{array}{l}\text { STATEN ISLAND } \\
\text { SAVINGS BANK }\end{array}$ & $10.8 / 30.7$ & $.78 / 3.18$ & $1.73 / 1.52$ \\
\hline $\begin{array}{l}\text { NATIONAL } \\
\text { STANDARD } \\
\text { MORTGAGE CORP. }\end{array}$ & $11.8 / 30.7$ & $.02 / .07$ & $3.22 / 1.52$ \\
\hline $\begin{array}{l}\text { RIDGEWOOD } \\
\text { SAVINGS BANK }\end{array}$ & $11.9 / 30.7$ & $.16 / .56$ & $3.11 / 1.52$ \\
\hline $\begin{array}{l}\text { RICHMOND } \\
\text { COUNTY } \\
\text { SAVINGS BANK }\end{array}$ & $12.9 / 30.7$ & $.48 / 1.69$ & $1.58 / 1.52$ \\
\hline $\begin{array}{l}\text { PROVIDENT BANK } \\
\text { THE NEW YORK } \\
\text { MORTGAGE CO. }\end{array}$ & $13.2 / 30.7$ & $.15 / .51$ & $3.75 / 1.52$ \\
\hline $\begin{array}{l}\text { FIRST UNION } \\
\text { NATIONAL BANK }\end{array}$ & $14.7 / 30.7$ & $.08 / .24$ & $1.73 / 1.52$ \\
\hline $\begin{array}{l}\text { THE YONKERS } \\
\text { SAVINGS \& LOAN }\end{array}$ & $15.2 / 30.7$ & $.07 / .20$ & $2.20 / 1.52$ \\
\hline
\end{tabular}

According to the HMDA data, these sixteen lenders combined made 3,990 conventional home mortgage loans in the New York metropolitan area in 1999, representing 6.3 percent of all conventional home mortgage loan originations. Since the metropolitan area average origination percentage to minority individuals was 30.7 , and according to the HMDA data no lender on this list made more than one-half of its conventional home mortgage loans to minority individuals - in fact, most made significantly less - no lender on this list made more than 15.35 percent of its conventional home mortgage loans to minority individuals in the metropolitan area in 1999. This means that, at most, these sixteen lenders combined made 612 conventional home mortgage loans to minority individuals in the metropolitan area in 1999, compared to the 1,225 conventional home mortgage loans they would have made to minority individuals had they originated conventional home mortgage loans to minorities at the metropolitan area rate, a gap of at least 613 loans.

According to the HMDA data, three lenders on this list, Safra National Bank of New York, Self-Reliance Federal Credit Union, and Suma (Yonkers) Federal Credit Union, made no conventional home mortgage loans to minority individuals in the metropolitan area in 1999. Had they originated loans to minority individuals at the metropolitan area rate, they would have made 54 conventional home mortgage loans to minority individuals. 
Two lenders on this list, Staten Island Savings Bank and Richmond County Savings Bank, were among the largest conventional home mortgage lenders in the New York metropolitan area in 1999, ranking 14th and 23rd respectively, originating 1400 and 722 loans each. Based on the origination percentage reported in Table Twelve, Staten Island Savings Bank made approximately 151 conventional home mortgage loans to minority individuals in the metropolitan area in 1999 compared to the 430 it would have made had it originated conventional home mortgage loans to minorities at the metropolitan area rate. Similarly, Richmond County Savings Bank made approximately 93 loans to minorities compared to the 222 loans it would have made at the metropolitan area rate.

Finally, nine of the sixteen lenders listed as having poor lending records to minority individuals are banks subject to the CRA. Their most recent CRA ratings ${ }^{40}$ are:

\begin{tabular}{|l|c|c|}
\hline \multicolumn{1}{|c|}{ BANK } & CRA RATING & YEAR \\
\hline $\begin{array}{l}\text { SAFRA NATIONAL BANK OF } \\
\text { NEW YORK }\end{array}$ & SATISFACTORY & 1997 \\
\hline THE BANK OF NEW YORK & SATISFACTORY & 1999 \\
\hline UNION STATE BANK & SATISFACTORY & 1999 \\
\hline
\end{tabular}

${ }^{40}$ See infra, note 15 , for more information about CRA ratings. It is important to note that a bank's CRA rating is based on more than just conventional home mortgage lending. It includes all of the bank's residential real estate-related lending and small business lending, and may include consumer lending as well. 12 C.F.R. $\S 25.22$ (2000). It also includes a bank's service and investment records. $I d$. at $\S \S 25.33,25.24$. The CRA rating is also based on lending according to borrower and neighborhood income. It is not based on lending according to the race of the borrower or the neighborhood. In addition, the CRA ratings of the banks on the following lists are not necessarily based on their lending performance in the New York metropolitan area. A bank receives its CRA rating based on its performance in its local CRA assessment area, even if it makes loans in other metropolitan areas. 12 U.S.C.A. $\S 2906$ (1989 \& Supp. 2000). If the CRA rating of a bank on any of the following lists is not based at least in part on its lending record in all or part of the New York metropolitan area, an * is placed next to its name. In effect, this means that even though the bank is subject to the CRA, it does not have CRA responsibilities in the New York Metropolitan area. The CRA examination reports for these banks are on file with the author. 


\begin{tabular}{|l|c|c|}
\hline $\begin{array}{l}\text { STATEN ISLAND SAVINGS } \\
\text { BANK }\end{array}$ & OUTSTANDING & 2000 \\
\hline RIDGEWOOD SAVINGS & SATISFACTORY & 1999 \\
\hline $\begin{array}{l}\text { RICHMOND COUNTY SAVINGS } \\
\text { BANK }\end{array}$ & SATISFACTORY & 1999 \\
\hline PROVIDENT BANK* & OUTSTANDING & 2000 \\
\hline $\begin{array}{l}\text { FIRST UNION NATIONAL BANK } \\
\text { THE YONKERS SAVINGS \& } \\
\text { LOAN }\end{array}$ & OUTSTANDING & 1997 \\
\hline
\end{tabular}

\section{b. LMI individuals}

There are 22 lenders that satisfy the criteria for having a poor conventional home mortgage lending record to LMI individuals. ${ }^{41}$

${ }^{41}$ The following five lenders should be added to Table Thirteen:

\section{Lender}

Homecomings

Financial Network

Bank United FSB

Olympia Mortgage

Corp.

GE Capital Mortgage

Services

Columbia Equities

$\frac{\text { Oritginations\% }}{1.1 / 12.7}$
$2.0 / 12.7$
$4.1 / 12.7$
$4.3 / 12.7$
$5.8 / 12.7$

Oritginations $\%$

\begin{tabular}{|c|c|}
\hline Market Share \% & Denial Rate Ratio \\
\hline $0.01 / 0.17$ & $3.04 / 1.68$ \\
\hline $0.01 / 0.08$ & $2.86 / 1.68$ \\
\hline $0.04 / 0.14$ & $9.3 / 1.68$ \\
\hline $0.15 / 0.48$ & $2.41 / 1.68$ \\
\hline $0.33 / 0.81$ & $2.10 / 1.68$ \\
\hline
\end{tabular}


Table Thirteen

LMI INDIVIDUALS

POOR LENDERING RECORDS

CONVENTIONAL HOME MORTGAGE LENDING

NEW YORK METROPOLITAN AREA, 1999

\begin{tabular}{|c|c|c|c|}
\hline LENDER & $\begin{array}{c}\text { ORIGINATIONS } \\
\text { (\%) } \\
\text { LENDER/MSA }\end{array}$ & $\begin{array}{c}\text { MARKET } \\
\text { SHARE (\%) } \\
\text { LMI/UI }\end{array}$ & $\begin{array}{c}\text { DENIAL } \\
\text { RATE RATIO } \\
\text { LENDER/MSA }\end{array}$ \\
\hline $\begin{array}{l}\text { BOSTON SAFE } \\
\text { DEPOSIT \& TRUST CO. }\end{array}$ & $0.0 / 12.7$ & $0.0 / .53$ & $12.96 / 1.68$ \\
\hline MELLON BANK & $0.0 / 12.7$ & $0.0 / .12$ & N/A \\
\hline $\begin{array}{l}\text { SAFRA NATIONAL } \\
\text { BANK OF NY }\end{array}$ & $0.0 / 12.7$ & $0.0 / .01$ & $\mathrm{~N} / \mathrm{A}$ \\
\hline $\begin{array}{l}\text { CHASE MANHATTAN } \\
\text { BANK, USA }\end{array}$ & $0.0 / 12.7$ & $0.0 / .21$ & $4.45 / 1.68$ \\
\hline SUMMIT BANK & $0.0 / 12.7$ & $0.0 / .06$ & $\mathrm{~N} / \mathrm{A}$ \\
\hline $\begin{array}{l}\text { US TRUST COMPANY } \\
\text { OF NEW YORK }\end{array}$ & $0.0 / 12.7$ & $0.0 / .33$ & $\mathrm{~N} / \mathrm{A}$ \\
\hline BANK OF NEW YORK & $1.1 / 12.7$ & $.01 / .17$ & $18.67 / 1.68$ \\
\hline $\begin{array}{l}\text { THE YONKERS } \\
\text { SAVINGS \& LOAN }\end{array}$ & $2.1 / 12.7$ & $.09 / .63$ & $3.55 / 1.68$ \\
\hline UNION STATE BANK & $2.2 / 12.7$ & $.03 / .16$ & $30.63 / 1.68$ \\
\hline $\begin{array}{l}\text { PNC MORTGAGE } \\
\text { CORP. OF AMERICA }\end{array}$ & $3.2 / 12.7$ & $.10 / .47$ & $7.54 / 1.68$ \\
\hline MORTGAGE.COM & $3.3 / 12.7$ & $.04 / .17$ & $1.94 / 1.68$ \\
\hline
\end{tabular}




\begin{tabular}{|l|c|c|c|}
\hline $\begin{array}{l}\text { APPLE BANK FOR } \\
\text { SAVINGS }\end{array}$ & $4.0 / 12.7$ & $.14 / .51$ & $1.77 / 1.68$ \\
\hline $\begin{array}{l}\text { RIDGEWOOD } \\
\text { SAVINGS BANK }\end{array}$ & $4.0 / 12.7$ & $.13 / .48$ & $3.54 / 1.68$ \\
\hline $\begin{array}{l}\text { ROYAL MORTGAGE } \\
\text { BANKERS }\end{array}$ & $4.0 / 12.7$ & $.03 / .09$ & $2.57 / 1.68$ \\
\hline $\begin{array}{l}\text { STERLING NATIONAL } \\
\text { MTG. CO. INC. }\end{array}$ & $4.6 / 12.7$ & $.10 / .31$ & $7.22 / 1.68$ \\
\hline \begin{tabular}{l} 
E-LOAN \\
\hline $\begin{array}{l}\text { STATEN ISLAND } \\
\text { SAVINGS BANK }\end{array}$
\end{tabular} & $6.2 / 12.7$ & $1.09 / 2.29$ & $2.87 / 1.68$ \\
\hline
\end{tabular}

According to the HMDA data, these 22 lenders combined made 4,734 conventional home mortgage loans in the New York metropolitan area in 1999, representing 7.5 percent of all conventional home mortgage loans. Since the New York metropolitan area average origination percentage to LMI persons was 12.7, and according to the HMDA data, no lender on this list made more than one-half of its conventional home mortgage loans to LMI persons in the metropolitan area in 1999 - in fact, many made far less - no lender on this list made more than 6.35 percent of its conventional home mortgage loans to LMI persons in the metropolitan area in 1999. This means that at most these sixteen lenders combined made approximately 301 conventional home mortgage loans to LMI individuals in the metropolitan area in 1999, compared to the 602 conventional home mortgage loans they would have made to LMI persons had they originated conventional home mortgage loans at the metropolitan area rate, a gap of at least 301 conventional home mortgage loans.

According to the HMDA data, 6 lenders on this list, Boston Safe Deposit \& Trust Co., Mellon National Bank, Safra National Bank of New York, Chase Manhattan Bank, USA, Summit Bank, and U.S. Trust Company of New York, made no conventional home mortgage loans to LMI persons in the New York metropolitan area in 1999. Had they originated conventional home mortgage loans to LMI persons at the 
metropolitan area rate, they would have made 97 conventional home mortgage loans to LMI persons.

Staten Island Savings bank is on this list. Based on the origination rate reported in Table Thirteen, it made approximately 87 conventional home mortgage loans to LMI persons in the metropolitan area in 1999, compared to the 178 it would have made had it originated conventional home mortgage loans at the metropolitan area rate.

Two lenders on the list, Mortgage.com and E-Loan, appear by their names to be internet-based lenders. Although their combined conventional home mortgage loan origination market share in the New York metropolitan area is small (.19 percent), it is noteworthy that LMI individuals is the only subject community for which they are listed as having a poor lending record. This is consistent with concerns that internet-based lending may not be available to LMI persons because they may not have access to computers.

Finally, thirteen of the twenty-two lenders on this list are banks subject to the CRA. Their most recent CRA ratings are: ${ }^{42}$

\begin{tabular}{|l|c|c|}
\hline \multicolumn{1}{|c|}{ BANK } & CRA RATING & YEAR \\
\hline MELLON BANK* & OUTSTANDING & 1997 \\
\hline $\begin{array}{l}\text { SAFRA NATIONAL } \\
\text { BANK OF NEW YORK }\end{array}$ & SATISFACTORY & 1997 \\
\hline $\begin{array}{l}\text { CHASE MANHATTAN } \\
\text { BANK, USA* }\end{array}$ & OUTSTANDING & 1999 \\
\hline SUMMIT BANK* & OUTSTANDING & 1999 \\
\hline $\begin{array}{l}\text { THE BANK OF NEW } \\
\text { YORK }\end{array}$ & SATISFACTORY & 1999 \\
\hline $\begin{array}{l}\text { THE YONKERS SAVINGS } \\
\text { \& LOAN }\end{array}$ & SATISFACTORY & 1999 \\
\hline UNION STATE BANK & SATISFACTORY & 1999 \\
\hline $\begin{array}{l}\text { APPLE BANK FOR } \\
\text { SAVINGS }\end{array}$ & SATISFACTORY & 1999 \\
\hline $\begin{array}{l}\text { RIDGEWOOD SAVINGS } \\
\text { BANK }\end{array}$ & SATISFACTORY & 2000 \\
\hline $\begin{array}{l}\text { STATEN ISLAND } \\
\text { SAVINGS BANK }\end{array}$ & OUTSTANDING & \\
\hline
\end{tabular}

42 The following banks should also be added to this list: Boston Safe Deposited Trust Co.* (outstanding - 1998); U.S. Trust Company of New York (CRA rating not available); Bank United FSB* (satisfactory - 2000). 


\section{c. Predominantly minority neighborhoods}

There are 25 lenders that satisfy the criteria for having a poor conventional home mortgage lending record in predominantly minority neighborhoods. ${ }^{43}$ This is the highest number of lenders on any of the four lists of poorly performing lenders.

\section{Table Fourteen}

PREDOMINANTLY MINORITY NEIGHBORHOODS

POOR LENDING RECORDS

CONVENTIONAL HOME MORTGAGE LENDING

NEW YORK METROPOLITAN AREA, 1999

\begin{tabular}{|l|c|c|c|}
\hline \multicolumn{1}{|c|}{ LENDER } & $\begin{array}{c}\text { ORIGINATIONS } \\
\text { (\%) } \\
\text { LENDER/MSA }\end{array}$ & $\begin{array}{c}\text { MARKET } \\
\text { SHARE (\%) } \\
\text { MIN./WHITE } \\
\text { NEIGHBORHOODS }\end{array}$ & $\begin{array}{c}\text { DENIAL } \\
\text { RATE RATIO } \\
\text { LENDER/MSA }\end{array}$ \\
\hline $\begin{array}{l}\text { FIRST FEDERAL } \\
\text { SAVINGS BANK }\end{array}$ & $0.0 / 10.3$ & $0.0 / .11$ & N/A \\
\hline $\begin{array}{l}\text { FT MORTGAGE } \\
\text { COMPANIES }\end{array}$ & $0.0 / 10.3$ & $0.0 / .09$ & $3.28 / 1.90$ \\
\hline $\begin{array}{l}\text { HUDSON VALLEY } \\
\text { BANK }\end{array}$ & $0.0 / 10.3$ & $0.0 / .10$ & N/A \\
\hline $\begin{array}{l}\text { KRAFT FOODS } \\
\text { FEDERAL CREDIT }\end{array}$ & $0.0 / 10.3$ & $0.0 / .06$ & N/A \\
\hline UNION & & & N/A \\
\hline $\begin{array}{l}\text { MAHOPAC } \\
\text { NATIONAL BANK }\end{array}$ & $0.0 / 10.3$ & $0.0 / .19$ & \\
\hline
\end{tabular}

${ }^{43}$ The following lender should be added to Table Fourteen:

First

\section{Origination\% Market Share\% Denial Rate Ratio}

Nationwide

$3.3 / 10.3$

$0.03 / 0.10$

$2.09 / 1.90$

Mortgage Corp. 


\begin{tabular}{|c|c|c|c|}
\hline MSDW CREDIT CORP. & $0.0 / 10.3$ & $0.0 / .11$ & $2.58 / 1.90$ \\
\hline $\begin{array}{l}\text { NORTHFIELD } \\
\text { SAVINGS BANK }\end{array}$ & $0.0 / 10.3$ & $0.0 / 31$ & N/A \\
\hline PEOPLE'S BANK & $0.0 / 10.3$ & $.03 / .09$ & N/A \\
\hline $\begin{array}{l}\text { POLISH \& SLAVIC } \\
\text { FEDERAL CREDIT } \\
\text { UNION }\end{array}$ & $0.0 / 10.3$ & $0.0 / .12$ & N/A \\
\hline $\begin{array}{l}\text { PREMIER NATIONAL } \\
\text { BANCORP }\end{array}$ & $0.0 / 10.3$ & $0.0 / .08$ & $5.67 / 1.90$ \\
\hline PROVIDENT BANK & $0.0 / 10.3$ & $0.0 / 39$ & N/A \\
\hline $\begin{array}{l}\text { PUTNAM COUNTY } \\
\text { SAVINGS BANK }\end{array}$ & $0.0 / 10.3$ & $0.0 / .27$ & N/A \\
\hline $\begin{array}{l}\text { ROYAL MORTGAGE } \\
\text { BANKERS }\end{array}$ & $0.0 / 10.3$ & $0.0 / .09$ & $2.41 / 1.90$ \\
\hline $\begin{array}{l}\text { SAFRA NATIONAL } \\
\text { BANK OF NY }\end{array}$ & $0.0 / 10.3$ & $0.0 / .19$ & $\mathrm{~N} / \mathrm{A}$ \\
\hline $\begin{array}{l}\text { SLEEPY HOLLOW } \\
\text { NATIONAL BANK }\end{array}$ & $0.0 / 10.3$ & $0.0 / .08$ & N/A \\
\hline $\begin{array}{l}\text { SOUND FEDERAL } \\
\text { S\&L }\end{array}$ & $0.0 / 10.3$ & $0.0 / 13$ & N/A \\
\hline $\begin{array}{l}\text { SUMA (YONKERS) } \\
\text { FEDERAL CREDIT } \\
\text { UNION }\end{array}$ & $0.0 / 10.3$ & $0.0 / .05$ & N/A \\
\hline UNION STATE BANK & $0.0 / 10.3$ & $0.0 / 16$ & $18.17 / 1.9$ \\
\hline $\begin{array}{l}\text { RICHMOND } \\
\text { COUNTY SAVINGS } \\
\text { BANK }\end{array}$ & $1.0 / 10.3$ & $.11 / 1.27$ & $10.19 / 1.9$ \\
\hline $\begin{array}{l}\text { INDEPENDENCE } \\
\text { COMMUNITY BANK }\end{array}$ & $1.5 / 10.3$ & $.06 / .47$ & $5.0 / 1.90$ \\
\hline
\end{tabular}




\begin{tabular}{|l|c|c|c|}
\hline $\begin{array}{l}\text { CHEVY CHASE } \\
\text { BANK }\end{array}$ & $1.6 / 10.3$ & $.02 / .11$ & $40.40 / 1.90$ \\
\hline $\begin{array}{l}\text { CENDANT } \\
\text { MORTGAGE }\end{array}$ & $2.3 / 10.3$ & $.55 / 2.69$ & $2.34 / 1.90$ \\
\hline $\begin{array}{l}\text { OHIO SAVINGS } \\
\text { BANK }\end{array}$ & $3.1 / 10.3$ & $.03 / .11$ & $2.28 / 1.90$ \\
\hline $\begin{array}{l}\text { M\&T MORTGAGE } \\
\text { CORP. }\end{array}$ & $3.3 / 10.3$ & $.46 / 1.57$ & $2.08 / 1.9$ \\
\hline
\end{tabular}

According to the HMDA data, these 25 lenders combined made 5,122 conventional home mortgage loans in the New York metropolitan area in 1999, representing 8.1 percent of all conventional home mortgage loans in the metropolitan area. Since the metropolitan area average origination percentage to predominantly minority neighborhoods was 10.3 , and according to the HMDA data, no lender on this list made more than one-half of its conventional home mortgage loans to predominantly minority neighborhoods in the metropolitan area in 1999 - in fact, most made far less - no lender on this list made more than 5.15 percent of its conventional home mortgage loans to predominantly minority neighborhoods in the metropolitan area in 1999 . This means that at most these 24 lenders made 264 conventional home mortgage loans to predominantly minority neighborhoods compared to the 528 conventional home mortgage loans they would have made to predominantly minority neighborhoods had they originated such loans at the metropolitan area rate, a gap of at least 264 loans.

According to the HMDA data, 18 lenders on this list, First Federal Savings Bank, FT Mortgage Companies, Hudson Valley Bank, Kraft Foods Federal Credit Union, Mahopac National Bank, MSDW Credit Corporation, Northfield Savings Bank, People's Bank, Polish \& Slavic Federal Credit Union, Premier National Bancorp, Provident Bank, Putnam County Savings Bank, Royal Mortgage Bankers, Safra National Bank of New York, Sleepy Hollow National Bank, Sound Federal Savings \& Loan, Suma (Yonkers) Federal Credit Union, and Union State Bank, made no loans to predominantly minority neighborhoods in the metropolitan area in 1999. Had they originated conventional home mortgage loans to predominantly minority neighborhoods at the 
metropolitan area rate, they would have made 152 conventional home mortgage loans to predominantly minority neighborhoods in the metropolitan area in 1999.

Three lenders on this list, Cendant Mortgage, M \& T Mortgage Corp., and Richmond County Savings Bank, were among the largest conventional home mortgage lenders in the New York metropolitan area in 1999, ranking 11 th, 20th, and 23rd respectively, with 1,554, 917, and 722 loans. Based on the origination percentages reported in Table Fourteen, Cendant Mortgage made approximately 36 conventional home mortgage loans to predominantly minority neighborhoods in the metropolitan area in 1999, compared to the 160 it would have made to predominantly minority neighborhoods had it originated conventional home mortgage loans at the metropolitan area rate. M \& T Mortgage Corp. made 30 loans compared to the 94 it would have made, and Richmond County Savings Bank made 7 loans compared to the 74 it would have made had it originated conventional home mortgage loans to predominantly minority neighborhoods at the metropolitan area rate in 1999. 
Finally, 16 of the 24 lenders on this list are banks subject to the CRA. Their most recent CRA ratings are: ${ }^{44}$

\begin{tabular}{|l|l|c|}
\hline \multicolumn{1}{|c|}{ BANK } & CRA RATING & YEAR \\
\hline $\begin{array}{l}\text { FIRST FEDERAL } \\
\text { SAVINGS BANK }\end{array}$ & SATISFACTORY & 1998 \\
\hline HUDSON VALLEY BANK & SATISFACTORY & 2000 \\
\hline $\begin{array}{l}\text { MAHOPAC NATIONAL } \\
\text { BANK }\end{array}$ & SATISFACTORY & 1996 \\
\hline $\begin{array}{l}\text { NORTHFIELD SAVINGS } \\
\text { BANK }\end{array}$ & SATISFACTORY & 1998 \\
\hline PEOPLE'S BANK* & OUTSTANDING & 1999 \\
\hline PROVIDENT BANK* & OUTSTANDING & 2000 \\
\hline $\begin{array}{l}\text { PUTNAM COUNTY } \\
\text { SAVINGS BANK }\end{array}$ & SATISFACTORY & 2000 \\
\hline $\begin{array}{l}\text { SAFRA NATIONAL } \\
\text { BANK OF NEW YORK }\end{array}$ & SATISFACTORY & 1997 \\
\hline $\begin{array}{l}\text { SLEEPY HOLLOW } \\
\text { NATIONAL BANK }\end{array}$ & SATISFACTORY & 2000 \\
\hline $\begin{array}{l}\text { SOUND FEDERAL } \\
\text { SAVINGS \& LOAN }\end{array}$ & SATISFACTORY & 1997 \\
\hline UNION STATE BANK & SATISFACTORY & 1999 \\
\hline $\begin{array}{l}\text { RICHMOND COUNTY } \\
\text { SAVINGS BANK }\end{array}$ & SATISFACTORY & 1999 \\
\hline $\begin{array}{l}\text { INDEPENDENCE } \\
\text { COMMUNITY BANK }\end{array}$ & SATISFACTORY & 2000 \\
\hline CHEVY CHASE BANK* & SATISFACTORY & 2000 \\
\hline OHIO SAVINGS BANK* & SATISFACTORY & 1999 \\
\hline
\end{tabular}

${ }^{44}$ In addition, the following bank should be added to the list: Premier National Bancorp* (satisfactory - 1999). 


\section{d. LMI neighborhoods}

There are 21 lenders that satisfy the criteria for having a poor conventional home mortgage lending record to LMI neighborhoods. ${ }^{45}$

TABLE FIFTEEN

LMI NEIGHBORHOODS

POOR LENDING RECORDS

CONVENTIONAL HOME MORTGAGE LENDING

NEW YORK METROPOLITAN AREA, 1999

\begin{tabular}{|l|c|c|c|}
\hline \multicolumn{1}{|c|}{ LENDER } & $\begin{array}{c}\text { ORIGINATIONS } \\
\text { (\%) } \\
\text { LENDER/MSA }\end{array}$ & $\begin{array}{c}\text { MARKET } \\
\text { SHARE (\%) } \\
\text { LMI/UI } \\
\text { NEIGBORHOODS }\end{array}$ & $\begin{array}{c}\text { DENIAL RATE } \\
\text { RATIO } \\
\text { LENDER/MSA }\end{array}$ \\
\hline $\begin{array}{l}\text { CHEVY CHASE } \\
\text { BANK }\end{array}$ & $0.0 / 8.8$ & $0.0 / .11$ & $10.10 / 1.73$ \\
\hline $\begin{array}{l}\text { CTX MORTGAGE } \\
\text { COMPANY }\end{array}$ & $0.0 / 8.8$ & $0.0 / .12$ & N/A \\
\hline $\begin{array}{l}\text { HUDSON VALLEY } \\
\text { BANK }\end{array}$ & $0.0 / 8.8$ & $0.0 / 0.10$ & N/A \\
\hline $\begin{array}{l}\text { KRAFT FOODS } \\
\text { FEDERAL CREDIT } \\
\text { UNION }\end{array}$ & $0.0 / 8.8$ & $0.0 / .06$ & N/A \\
\hline
\end{tabular}

${ }^{45}$ The following lenders should be added to Table Fifteen:

\begin{tabular}{|c|c|c|c|}
\hline$\frac{\text { Lender }}{\text { Standard Federal }}$ & Origination \% & Market Share \% & Denial Rate Ratio \\
\hline Bank & $1.3 / 8.8$ & $0.13 / 0.96$ & $4.47 / 1.73$ \\
\hline First Nationwide & & & \\
\hline Mortgage Corp. & $3.3 / 8.8$ & $0.04 / 0.10$ & $2.02 / 1.73$ \\
\hline
\end{tabular}




\begin{tabular}{|c|c|c|c|}
\hline $\begin{array}{l}\text { MAHOPAC } \\
\text { NATIONAL BANK }\end{array}$ & $0.0 / 8.8$ & $0.0 / .18$ & N/A \\
\hline $\begin{array}{l}\text { NATIONAL } \\
\text { STANDARD } \\
\text { MORTGAGE CORP. }\end{array}$ & $0.0 / 8.8$ & $0.0 / .06$ & N/A \\
\hline $\begin{array}{l}\text { PREMIER } \\
\text { NATIONAL } \\
\text { BANCORP }\end{array}$ & $0.0 / 8.8$ & $0.0 / .10$ & N/A \\
\hline $\begin{array}{l}\text { PUTNAM COUNTY } \\
\text { SAVINGS BANK }\end{array}$ & $0.0 / 8.8$ & $0.0 / .27$ & N/A \\
\hline $\begin{array}{l}\text { SOUND FEDERAL } \\
\text { S\&L }\end{array}$ & $0.0 / 8.8$ & $0.0 / .13$ & N/A \\
\hline $\begin{array}{l}\text { ULSTER SAVINGS } \\
\text { BANK }\end{array}$ & $0.0 / 8.8$ & $0.0 / .25$ & N/A \\
\hline $\begin{array}{l}\text { UNION STATE } \\
\text { BANK }\end{array}$ & $0.0 / 8.8$ & $0.0 / .16$ & $18.17 / 1.73$ \\
\hline $\begin{array}{l}\text { U S TRUST } \\
\text { COMPANY }\end{array}$ & $0.5 / 8.8$ & $.02 / .32$ & $36.67 / 1.73$ \\
\hline $\begin{array}{l}\text { RIDGEWOOD } \\
\text { SAVINGS BANK }\end{array}$ & $1.2 / 8.8$ & $.05 / .44$ & $1.86 / 1.73$ \\
\hline $\begin{array}{l}\text { BOSTON SAFE } \\
\text { DEPOSIT \& TRUST } \\
\text { CO. }\end{array}$ & $1.5 / 8.8$ & $.07 / .46$ & $3.66 / 1.73$ \\
\hline $\begin{array}{l}\text { CENDANT } \\
\text { MORTGAGE }\end{array}$ & $2.1 / 8.8$ & $.58 / 2.65$ & $2.82 / 1.73$ \\
\hline $\begin{array}{l}\text { THE WARWICK } \\
\text { SAVINGS BANK }\end{array}$ & $3.3 / 8.8$ & $.05 / .15$ & $4.84 / 1.73$ \\
\hline $\begin{array}{l}\text { AMERICAN HOME } \\
\text { MORTGAGE CORP. }\end{array}$ & $3.4 / 8.8$ & $.93 / 2.59$ & $2.44 / 1.73$ \\
\hline
\end{tabular}




\begin{tabular}{|l|c|c|c|}
\hline FLAGSTAR BANK & $3.9 / 8.8$ & $.52 / 1.25$ & $2.62 / 1.73$ \\
\hline $\begin{array}{l}\text { ASTORIA FEDERAL } \\
\text { SAVINGS }\end{array}$ & $4.1 / 8.8$ & $1.01 / 2.27$ & $2.07 / 1.73$ \\
\hline
\end{tabular}

According to the HMDA data, these 21 lenders combined made 7,490 conventional home mortgage loans in the New York metropolitan area in 1999, representing 11.88 percent of all conventional home mortgage loans in the metropolitan area. Since the New York metropolitan area average origination percentage to LMI neighborhoods was 8.8 , and according to the HMDA data, no lender on this list made more than one-half of its conventional home mortgage loans to LMI neighborhoods in the metropolitan area in 1999 - in fact, most made far less - no lender on this list made more than 4.4 percent of its conventional home mortgage loans to LMI neighborhoods. This means that at most these 21 lenders made 330 conventional home mortgage loans to LMI neighborhoods in the metropolitan area in 1999, compared to the 660 conventional home mortgage loans they would have made to LMI neighborhoods had they originated loans at the metropolitan area rate, a gap of at least 330 loans.

According to the HMDA data, 11 lenders on this list, Chevy Chase Bank, CTX Mortgage Company, Hudson Valley Bank, Kraft Foods Federal Credit Union, Mahopac National Bank, National Standard Mortgage Corp., Premier National Bancorp, Putnam County Savings Bank, Sound Federal Savings \& Loan, Ulster Savings Bank, and Union State Bank, made no conventional home mortgage loans to LMI neighborhoods in the metropolitan area in 1999. Had they made loans to LMI neighborhoods at the New York metropolitan area rate, they would have made 77 conventional home mortgage loans to LMI neighborhoods in the metropolitan area in 1999.

Four lenders on this list, Cendant Mortgage, American Home Mortgage Corp., Astoria Federal Savings, and Flagstar Bank, were among the largest conventional home mortgage lenders in the New York metropolitan area in 1999, ranking 11th, 12th, 16th, and 22nd, respectively, with 1554, 1536, 1360, and 744 loans. Based on the origination percentage reported in Table Fifteen, Cendant Mortgage made approximately 33 conventional home mortgage loans to LMI 
neighborhoods in the metropolitan area in 1999 compared to the 137 loans it would have made to LMI neighborhoods had it made conventional home mortgage loans to LMI neighborhoods at the metropolitan area rate. The relevant numbers for the other lenders are: American Home Mortgage Corp. - 52/135; Astoria Federal Savings 56/120; and Flagstar Bank - 29/65.

Finally, fifteen of the nineteen lenders on this list are banks subject to the CRA. Their most recent CRA ratings are: ${ }^{46}$

\begin{tabular}{|c|c|c|}
\hline BANK & CRA RATING & YEAR \\
\hline CHEVY CHASE BANK* & SATISFACTORY & 2000 \\
\hline HUDSON VALLEY BANK & SATISFACTORY & 2000 \\
\hline MAHOPAC NATIONAL BANK & SATISFACTORY & 1996 \\
\hline $\begin{array}{l}\text { PUTNAM COUNTY SAVINGS } \\
\text { BANK }\end{array}$ & SATISFACTORY & 2000 \\
\hline $\begin{array}{l}\text { SOUND FEDERAL SAVINGS } \\
\& \text { LOAN }\end{array}$ & SATISFACTORY & 1997 \\
\hline ULSTER SAVINGS BANK* & SATISFACTORY & 1999 \\
\hline UNION STATE BANK & SATISFACTORY & 1999 \\
\hline RIDGEWOOD SAVINGS BANK & SATISFACTORY & 1999 \\
\hline $\begin{array}{l}\text { THE WARWICK SAVINGS } \\
\text { BANK }\end{array}$ & SATISFACTORY & 1998 \\
\hline FLAGSTAR BANK* & SATISFACTORY & 1999 \\
\hline ASTORIA FEDERAL SAVINGS & OUTSTANDING & 1999 \\
\hline
\end{tabular}

${ }^{46}$ In addition, the following three banks should be added to this list: Premier National Bancorp* (satisfactory - 1999); U.S. Trust Company of New York (CRA rating not available); Standard Federal Bank* (outstanding - 1998). 


\section{CONCLUSIONS AND POLICY RECOMMENDATIONS}

Among the many conclusions about residential real estate-related lending and conventional home mortgage lending in the New York metropolitan area that can be derived from the 1999 Scorecard, the following four have significant policy implications.

*The importance of applications: Overall, when looking at both the residential real estate-related and conventional home mortgage lending Scorecards, the control communities outperformed the corresponding subject communities in loan originations, doing better than the subject communities in five of eight opportunities. On each of these occasions, the control communities also outperformed the corresponding subject communities in applications submitted. On two of the three occasions that the subject communities outperformed the control communities in originations, they outperformed the corresponding control communities in applications submitted. The only time this relationship between applications submitted and loans originated did not hold, the denial rate ratio dropped significantly for the subject community. These results suggest that in order to increase originations in the subject communities relative to control communities, lenders should expand efforts to generate applications from the subject communities or work to reduce differential treatment of applications from the subject communities.

* Subprime lending patterns: Subprime lending was generally down in all communities under study in 1999, although the rate of decline was greater in the control communities and subprime lending was a much greater part of lending in the subject communities than the control communities. Perhaps one of the reasons for the decline in subprime lending is the continuing effort by activists and government officials to curtail abusive lending practices. The fact that subprime lending is still a significant part of lending in the subject communities suggests that these efforts should continue and expand. In particular, the federal banking regulatory agencies could take account of abusive lending practices when examining banks for CRA compliance.

${ }^{*}$ Lenders with poor lending records in the subject communities: Among the 56 lenders who had a poor lending record in at least one subject community, 28 lenders made no loans in at least one subject community, 22 had a poor lending record in more than one subject 
community, 7 were relatively large lenders, and 34 were banks subject to the CRA. Efforts to improve lending in the subject communities by focusing on these lenders could make a significant impact. In particular, the federal banking agencies could strengthen their enforcement of the CRA. None of the banks listed among the lenders with a poor lending record in at least one subject community had a CRA rating of less than satisfactory. Eighteen of these banks made no loans to at least one subject community. Twelve of the banks, although subject to the CRA, are not required to fulfill CRA obligations in the New York metropolitan area because they do not include the metropolitan area in their CRA assessment area.

*Evidence of lending discrimination: Denial rate ratios for African-Americans, Native Americans, and predominantly minority neighborhoods are consistent with discrimination against these communities. Government agencies with fair lending jurisdiction over lenders, including the Department of Justice, HUD, the federal banking regulatory agencies, and the New York State Banking Department, should use their authority to investigate the evidence of lending discrimination and take any necessary steps to stop it. 
